Rosemary Aparecida de Oliveira

\title{
Avaliação do efeito antimicrobiano in vitro de quitosana e da associação quitosana/clorexidina sobre saliva e Streptococcus mutans
}

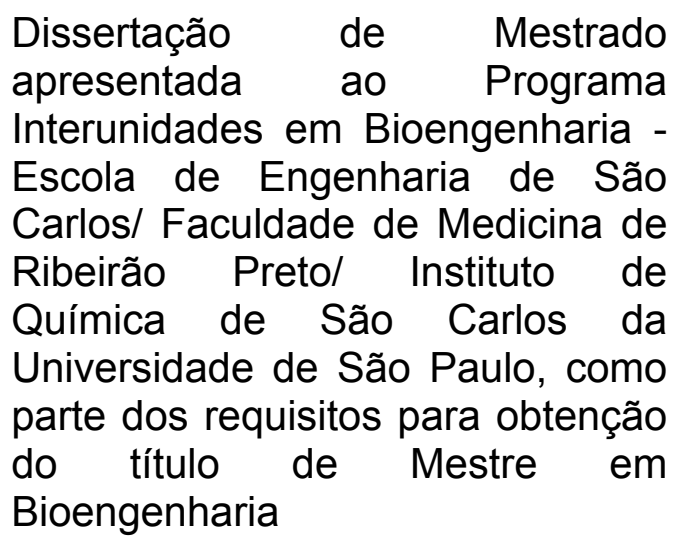

Orientador: Prof. Dr. Ana Maria de Guzzi Plepis

São Carlos

2004 
Dedico este trabalho a Deus, por permitir que eu pudesse transpor os espinheiros de seu jardim para enfim aspirar o perfume exalado. 


\section{AGRADECIMENTOS}

A Prof ${ }^{a}$. Dra . Ana Maria de Guzzi Plepis pela dedicação e orientação, sem as quais não seria possível realizar este sonho e acima de tudo pela paciência, delicadeza, confiança e compreensão nos momentos conturbados.

Aos professores do programa de Pós-Graduação Interunidades em bioengenharia.

Aos funcionários do Laboratório de Bioquímica e Biomateriais do IQSC, sem os quais seria inviável a realização deste trabalho.

Aos funcionários do departamento de Microbiologia da Universidade Barão de Mauá pelos esclarecimentos e auxílio.

Ao aluno de doutorado André Pitondo da Silva pela paciência e ajuda.

A Gracie Luiza da Silva pela colaboração, incentivo e apoio.

A todos que direta ou indiretamente contribuíram para a realização deste feito.

E principalmente a todas as pessoas que amo, pois sem elas qualquer sonho ou desejo em minha vida não teria significado. 


\begin{abstract}
OLIVEIRA, R. A. (2004) Evaluation of in vitro antimicrobial effect of chitosan and chitosan/ chlorhexidine on saliva and Streptococcus mutans. São Carlos, 2004, 00 p. Essay (Master’s Degree) - São Carlos Engeneering School/ Ribeirão Preto Medicine College/ São Carlos chemical Institute, São Paulo University.
\end{abstract}

Saliva and Streptococcus mutans were used to evaluate antimicrobial activity of chitosan/ chlorexidine solutions. Antimicrobial tests were conducted using chitosan and chitosan/ chlorexidine solutions in $1.0 \%$ acetic acid solution, at various $\mathrm{pH}$ values (3.5-5.0) and concentrations ranging from 0.1 to $1.5 \%(\mathrm{w} / \mathrm{v})$. Prior to each experiment, chitosan (DA $76 \%, 400.000 \mathrm{~g} / \mathrm{mol}$ ) stock solution $\mathrm{pH}$ was adjusted to the desired $\mathrm{pH}$ using $\mathrm{NaOH}$. The antimicrobial activity increased with $\mathrm{pH}$, concentration, exposition time and with the association of chitosan and chlorexidine. Increasing the concentration of chlorexidine did not have a significant effect indicating that in presence of chitosan it is possible to deliver this compound at a lower concentration which will avoid unwanted side effects including staining and altered taste sensations.

Key-words: chitosan, chlorhexidine, saliva, Streptococcus mutans, antimicrobial activity. 


\section{RESUMO}

OLIVEIRA, R. A. (2004) Avaliação do efeito antimicrobiano in vitro de quitosana e da associação quitosana/ clorexidina sobre saliva e Streptococcus mutans. São Carlos, 2004, 00p.Dissertação (Mestrado) - Escola de Engenharia de São Carlos/ Faculdade de medicina de Ribeirão Preto/ Instituto de Química de São Carlos, Universidade de São Paulo.

Saliva e Streptococcus mutans foram utilizados neste estudo para avaliar a atividade antimicrobiana da quitosana associada à clorexidina. Os testes de atividade antimicrobiana foram realizados utilizando-se soluções de quitosana e quitosana:clorexidina preparadas em ácido acético 1\%, em diversos valores de $\mathrm{pH}(3,5-5,0)$ e valores de concentração variando entre 0,1 e 1,5\% (m/v). Antes de cada experimento o pH da solução estoque de quitosana (grau de desacetilação $76 \%$ e massa molar $400.000 \mathrm{~g} / \mathrm{mol}$ ) foi ajustado até o $\mathrm{pH}$ desejado pela adição de $\mathrm{NaOH}$. A atividade antimicrobiana aumentou com o pH, com a concentração, com o tempo de exposição e com a associação quitosana/ clorexidina. Aumentando-se a concentração de clorexidina não se observam efeitos significativos, indicando que em presença de quitosana é possível liberar este composto em concentrações menores, o que irá minimizar os efeitos colaterais indesejados de pigmentação e sensação de alteração de sabor.

Palavras chave : quitosana, clorexidina, saliva, Streptococcus mutans, atividade antimicrobiana. 


\section{LISTA DE FIGURAS}

FIGURA 1- Streptococcus mutans.

FIGURA 2- Digluconato de clorexidina.

FIGURA 3- Representação esquemática das estruturas de celulose e

quitina.

FIGURA 4- Representação esquemática da estrutura de quitosana, com x representando o grau de acetilação.

FIGURA 5- Esquema da obtenção de quitina e quitosana.

FIGURA 6- Preparo das amostras estudadas.

FIGURA 7- Representação esquemática da técnica utilizada no teste de contato direto.

FIGURA 8- Esquema da técnica utilizada nos testes de atividade.

FIGURA 9- Esquema do teste de simulação de bochecho.

FIGURA 10- Espectro de absorção na região do infravermelho para

membranas de quitosana e quitosana com clorexidina.

FIGURA 11- Curvas DSC de quitosana $\left(1 \mathrm{M}_{\mathrm{A}}\right)$ e quitosana com

clorexidina $\left(\mathrm{N}_{2}\right)$.

FIGURA 12- Curva DSC de quitosana com clorexidina (ar). 64

FIGURA 13- Curva de DSC para a clorexidina (ar).

FIGURA 14- Curva TG para as matrizes de quitosana, quitosana

com clorexidina $\left(\mathrm{N}_{2}\right)$ e quitosana com clorexidina (ar). 
FIGURA 15- Fotomicrografias da superfície das matrizes de quitosana $0,1 \%$, preparadas com ácido acético 1\% (aumento de 200 vezes). A- quitosana Bquitosana/ clorexidina.

FIGURA 16- Fotomicrografias da superfície das matrizes de quitosana $0,1 \%$, preparadas com ácido acético 1\% (aumento de 1000 vezes). A- quitosana B- quitosana/ clorexidina.

FIGURA 17- Microrganismos totais, amostra de saliva cultivada em ágar sangue, após 72 horas de incubação.

FIGURA 18- Amostra de saliva em MSB isolamento de Streptococcus mutans, após 48 horas de incubação.

FIGURA 19- Amostra de Streptococcus mutans em ágar sangue utilizada para o teste de sensibilidade 1- $\mathrm{pH}$ 3,5; 2- $\mathrm{pH} 4,0 ; 3-\mathrm{pH} 4,5$ e 4- $\mathrm{pH}$ 5,0, após 48 horas de incubação.

FIGURA 20- Efeito da concentração de quitosana sobre a saliva cultivada em ágar sangue, após 72 horas de incubação (1) Quitosana 0,5\%;

(2) Quitosana 0,1\%; (3) Controle, sem adição de quitosana;

(4) Quitosana 1,5\%; (5) Quitosana 1,0\%.

FIGURA 21- Densidade óptica das amostras expostas as soluções de quitosana e das soluções de quitosana.

FIGURA 22- Efeito inibitório da quitosana a 1,5\% sobre Streptococcus mutans em função do tempo de exposição (1) 2 minutos, (2) 3 minutos, (3) 4 minutos, (4) 5 minutos, meio MSB, após 48 horas de incubação. 


\section{LISTA DE TABELAS}

Tabela 1. Microbiota oral

Tabela 2. Fontes naturais de quitina e quitosana

Tabela 3 Composição do Ágar Mueller hinton

Tabela 4. Composição do ágar sangue

Tabela 5. Composição do Brain Heart Infusion

Tabela 6. Composição do Ágar Mitis salivarius

Tabela 7. Composição do Letheen Broth

Tabela 8. Distribuição dos tubos

Tabela 9. Influência do pH no efeito inibitório

Tabela 10. Influência da concentração no efeito inibitório

Tabela 11. Efeito das soluções no efeito inibitório

Tabela 12. Efeito das diferentes soluções sobre a saliva

Tabela 13. Efeito das diferentes soluções sobre Streptococcus mutans

Tabela 14. Efeito das soluções sobre Streptococcus mutans

82

Tabela 15. Efeito das soluções sobre a saliva 


\section{SUMÁRIO}

LISTA DE FIGURAS

LISTA DE TABELAS

RESUMO

ABSTRACT

$\begin{array}{ll}\text { I. INTRODUÇÃO } & 12\end{array}$

I.1. MICROBIOTA ORAL 12

$\begin{array}{ll}\text { I.2. CÁRIE } & 14\end{array}$

$\begin{array}{ll}\text { I.3. Streptococcus mutans } & 15\end{array}$

$\begin{array}{lr}\text { I.4. CLOREXIDINA } & 18\end{array}$

$\begin{array}{ll}\text { I.5. QUITINA / QUITOSANA } & 22\end{array}$

I.6. QUITOSANA - EFEITO ANTIMICROBIANO 29

$\begin{array}{ll}\text { II. OBJETIVOS } & 35\end{array}$

III. MATERIAIS E MÉTODOS 36

III.1. MEIOS DE CULTURA 36

$\begin{array}{ll}\text { III.1.1. Preparo dos meios de cultura } & 38\end{array}$

III.1.1.1. Ágar Müeller Hinton $\quad 39$

III.1.1.2. Ágar sangue $\quad 40$

$\begin{array}{ll}\text { III.1.1.3. Brain Heart Infusion (BHI) } & 41\end{array}$

III.1.1.4. Ágar Mitis Salivarius com bacitracina (MSB) 42

$\begin{array}{ll}\text { III.1.1.5. Letheen Broth } & 43\end{array}$

III.2. PREPARO DAS SOLUÇÕES 43 
III.5. TESTES PRELIMINARES $\quad 50$

III.5.1. TESTES DE SENSIBILIDADE $\quad 50$

III.5.2. TESTES DE CONTATO DIRETO 51

III.6. ANÁLISE DA DENSIDADE ÓPTICA

III.7. TESTES DE ATIVIDADE $\quad 56$

III.8. TESTES DE SIMULAÇÃO DE BOCHECHO 57

IV. RESULTADOS E DISCUSSÃO

IV.1. CARACTERIZAÇÃO

$\begin{array}{ll}\text { IV.2. AMOSTRAS E SOLUÇÕES } & 67\end{array}$

$\begin{array}{ll}\text { IV.3. TESTES PRELIMINARES } & \mathbf{7 0}\end{array}$

$\begin{array}{ll}\text { IV.3.1. Testes de sensibilidade } & 70\end{array}$

$\begin{array}{ll}\text { IV.3.2. Testes de contato direto } & 72\end{array}$

IV.4. ANÁLISE DA DENSIDADE ÓPTICA 76

$\begin{array}{ll}\text { IV.5. TESTES DE ATIVIDADE } & 79\end{array}$

IV.6. TESTES DE SIMULAÇÃO DE BOCHECHOS 82

V. CONCLUSÕES

VI. REFERÊNCIAS BIBLIOGRÁFICAS

$\begin{array}{ll}\text { ANEXO } 1 & 94\end{array}$

$\begin{array}{lr}\text { ANEXO } 2 & 96\end{array}$ 


\section{INTRODUÇÃO}

A cárie e a doença periodontal estão diretamente relacionadas às bactérias presentes na boca e devido às implicações destas doenças na vida de um indivíduo, programas preventivos são realizados.

O concurso "A Saúde Bucal" realizado em 2003 pelo Conselho Regional de Odontologia do Estado de São Paulo e pela Secretaria do Estado e da Educação visou a promoção da saúde bucal através da educação, enfatizando que a prevenção é a melhor alternativa.

O uso de produtos complementares, como antissépticos para uma higienização adequada, merece destaque no combate as doenças bucais.

\section{I.1. MICROBIOTA ORAL}

Numerosos sítios ecológicos compõem a cavidade oral, sendo os mais importantes: epitélios, dentes, próteses, saliva e líquido gengival (PONTON, 2000).

A cavidade oral está constantemente em contato com microrganismos do meio ambiente e é normalmente colonizada por certas espécies microbianas. A mistura destes microrganismos regularmente encontrados neste sítio anatômico é designada de flora normal.

Uma grande variedade de microrganismos está presente na cavidade oral e as diferentes situações ecológicas que ocorrem neste sítio no 
decorrer da vida levam a uma mudança correspondente na flora normal, inclusive aumentando a sua complexidade (SILVA,1999). Ao nascer o indivíduo possui a cavidade oral asséptica, sendo rapidamente colonizada com o meio ambiente, a bactéria predominante neste período é o Streptococcus salivarius. A erupção dos dentes leva a colonização por Streptococcus mutans e Streptococcus sanguis, permanecendo estes enquanto houver dentes.

A tabela 1 mostra os principais microrganismos presentes na cavidade oral distribuídos de forma percentual.

Tabela 1. Microbiota oral (PONTON, 2000)

\begin{tabular}{|l|c|}
\hline Microorganismo & $\%$ \\
\hline Streptococcus & 52 \\
\hline Actinomyces & 15 \\
\hline Lactobacillus & 1 \\
\hline Neisseria & 2 \\
\hline Veillonella & 1 \\
\hline Prevotella & 4 \\
\hline Candida & $<1$ \\
\hline
\end{tabular}

A microbiota oral, em particular os Streptococus do grupo mutans, está diretamente relacionada com a formação do biofilme bacteriano e com as doenças dele decorrentes. A redução desses microorganismos está assim intimamente ligada à prevenção e ao controle de afecções que acometem a boca. Devido a estes fatores, vários produtos são utilizados e novos são colocados no 
mercado a cada dia com este intuito, sendo que a maior parte deles é derivada de clorexidina, reconhecida tanto por sua eficácia como por seus efeitos adversos (BOWDEN, 1996). Dadas às características da quitosana, sua utilização poderia contribuir incisivamente para o tratamento e prevenção de patologias orais, como por exemplo, a cárie e doenças periodontais.

\section{I.2. CÁRIE}

A cárie é uma doença multicausal, na qual a presença de uma microbiota específica relaciona-se positivamente com o surgimento de lesões (HOLBROOK, 1993). Os principais microrganismos cariogênicos são os Streptococcus mutans (HOLBROOK, 1993). Devido a sua associação com a cárie, uma avaliação destes microrganismos no biofilme dentário e na saliva pode ser útil como auxiliar no diagnóstico da doença. Em conjunto com este conceito, o controle e prevenção de cáries têm sido relacionados a uma redução do número de bactérias que colonizam a cavidade oral de um indivíduo (ZICKERT et al., 1983; GISSELSSON et al., 1988; BOWDEN, 1996).

O caráter infecto-contagioso da doença implica a adoção de medidas que visem reduzir o número de microrganismos cariogênicos através de antimicrobianos específicos (KÖHLER et al., 1983). O controle microbiológico associado ao tratamento restaurador é fundamental para restabelecer a saúde bucal do individuo (ZICKERT et al., 1987). 
Devido à relação direta entre o número de Streptococcus mutans na saliva e o número de sítios intra-orais colonizados, a quantificação destes microrganismos na saliva é justificável (TOGELIUS et al., 1984; DASANAYAKE et al., 1995).

Para o controle da cárie dentária no mundo desenvolvido, o meio mais comum é a remoção mecânica do biofilme bacteriano por escovação utilizando-se dentifrícios (FRANDSEN, 1986). Um nível aceitável de higiene oral é dificilmente atingido pelo método mecânico devido à dificuldade dos pacientes, por isso agentes antimicrobianos estão sendo incorporados em soluções para bochecho e dentifrícios como suplementos a higienização tradicional (LINDHE et al., 1984; RAMBERG et al., 1992; OWENS, 1997).

Os dentifrícios são substâncias usadas durante a escovação dental com finalidades cosméticas: limpando, polindo e tornando o hálito fresco bem como finalidades terapêuticas: removendo placa dental e/ou restos alimentares e aplicando substâncias cariostáticas e antimicrobianas, prevenindo a formação de lesões cariosas e periodontais. Os enxaguatórios bucais usados, antes ou após a escovação devem ser considerados como coadjuvantes na higiene oral (OWENS et al., 1997).

\section{I.3. Streptococcus mutans}

Os estreptococos compreendem um conjunto heterogêneo de cocos que se dividem num só plano, agrupando-se em cadeias de tamanho 
variável, embora esses microrganismos façam parte da microbiota normal, muitos deles são considerados importantes agentes infecciosos para o homem e para os animais.

Seu metabolismo é fermentativo e o ácido lático é o produto final predominante da fermentação da glicose. A classificação dos estreptococos é bastante complexa e vários são os sistemas utilizados para este fim, dentre eles se destacam aqueles baseados em características hemolíticas, fisiológicas e antigênicas.

Um sistema conveniente de diferenciação dos estreptococos de importância médica permite dividí-los nas seguintes categorias: estreptococos beta-hemolíticos, Streptococcus pneumoniae, estreptococos do complexo "Streptococcus bovis/ Streptococcus equinus" e estreptococos do grupo "viridans".

A maioria das espécies englobadas nos estreptococos do grupo viridans faz parte da flora normal da cavidade oral e são alocadas em cinco principais grupos de espécies: Streptococcus mutans, Streptococcus salivarius, Streptococcus sanguis, Streptococcus mitis e Streptococcus anginosus. Como agentes etiológicos são associados a bacteremia, endocardite, abscessos, infecções do trato geniturinário e infecções de feridas.

Os Streptococcus mutans são cocos gram-positivos, alfahemolíticos (causam lise parcial das hemácias) e anaeróbios facultativos. O aumento destes microrganismos está relacionado com o alto consumo de açúcar combinado com a diminuição do pH da cavidade oral. 
Os Streptococcus mutans são equipados com um sistema eficiente de transporte de açúcar para dentro de suas células (HAMADA \& SLADE, 1980). Durante seu metabolismo eles produzem várias substâncias que contribuem consideravelmente para sua patogenicidade, quando altos níveis de açúcar são consumidos estes microrganismos produzem principalmente o ácido lático, quando comparados com outras bactérias eles são muito mais rápidos nesta produção (HAMADA \& SLADE, 1980; LOESCHE, 1986). O metabolismo dos Streptococcus mutans pode ocorrer em meio ácido ou neutro e sua atividade continua mesmo em baixos valores de pH (KÖHLER et al., 1995). A figura 1 ilustra os Streptococcus mutans.

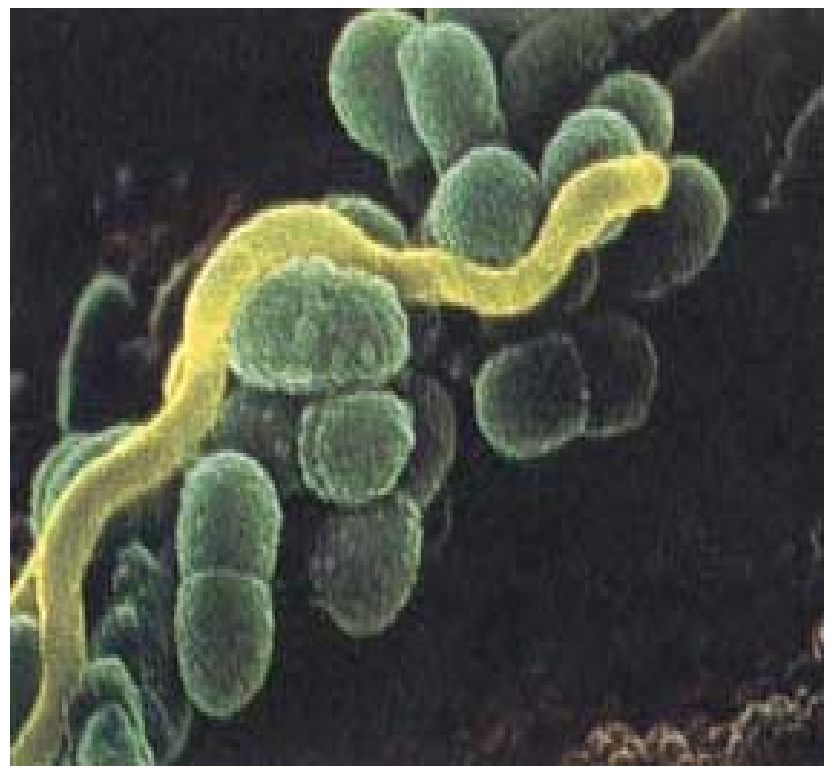

FIGURA 1- Streptococcus mutans

A produção de polissacarídeos extracelulares, devido a viscosidade, favorece a aderência desta bactéria à superfície dentária, pois 
possibilita a instalação em superfícies lisas (KOGA et al., 1986; LOESCHE,1986). Os polissacarídeos intracelulares produzidos pelos Streptococcus mutans asseguram a própria sobrevivência destes microrganismos durante intervalos de baixa nutrição e são usados pelos mesmos para produzir mais ácidos (HAMADA \& SLADE, 1980).

\section{I.4. CLOREXIDINA}

A clorexidina, entre as drogas usadas como antimicrobianos, é a substância melhor documentada e que apresenta melhores resultados (KIDD, 1991). Sendo eficaz na prevenção e controle de doenças orais, portanto recomendada e usada na prática clínica odontológica (BELLINI et al., 1980) é capaz de inibir a formação de placa e ácidos por períodos prolongados de tempo graças à capacidade de substantividade (VAAHTONIEMI, 1994).

A clorexidina é uma bisguanidina com propriedades catiônicas. A molécula é simétrica (figura 2), com dois anéis 4 cloro-fenil e dois grupos etano pentânicos ligados por uma cadeia central do hexametileno. A clorexidina é um pó sem cheiro, de coloração branca-amarelo pálida com um caráter fortemente básico. Seus sais mais importantes são o diacetato de clorexidina, o digluconato de clorexidina e o dicloridrato de clorexidina (SANCHEZ COLLADO \& CIA, 2003).

Em soluções aquosas, os sais de clorexidina alcançam a atividade microbiológica máxima e estabilidade de substância química em uma faixa de $\mathrm{pH}$ 
entre 5 e 8 . O efeito germicida dos sais de clorexidina é dependente do tempo de exposição, da temperatura e do pH (SANCHEZ COLLADO \& CIA, 2003)

A análise do mecanismo de ação antimicrobiana da clorexidina em função da concentração, estudado por HELGELAND et al. (1971), demonstrou que o aumento desta conduz a um decréscimo na atividade intracelular dos microrganismos patogênicos, o que levaria a liberação e/ou desnaturação das enzimas proteolíticas que constituem a membrana celular microbiana.

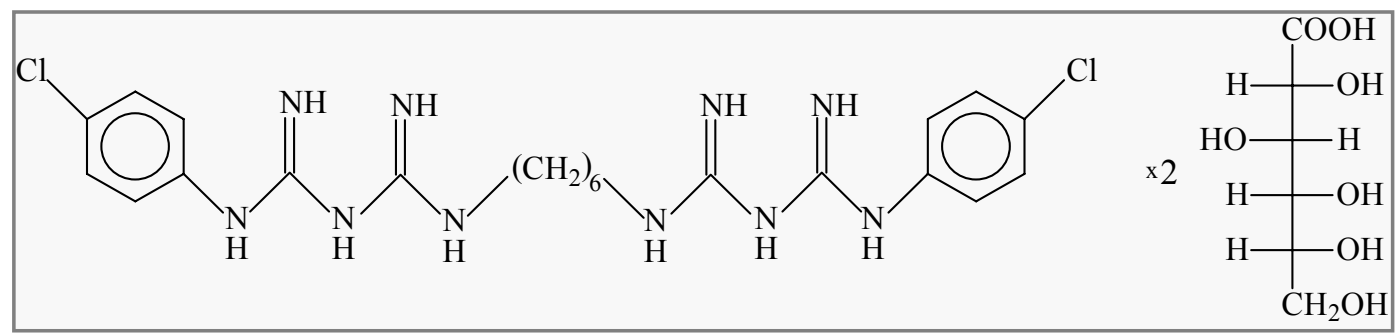

FIGURA 2- Digluconato de clorexidina

HENNESSEY (1973), verificando as propriedades antimicrobianas da clorexidina, relatou que essa substância apresenta eficiente ação, sendo que os microorganismos Gram positivos são mais sensíveis que os Gram negativos e que os estafilococos mostraram-se mais resistentes que os estreptococos, relata também que o mecanismo de ação da clorexidina que resulta em efeito antimicrobiano, começa com sua adsorção na superfície da célula bacteriana, provocando pequenas rupturas na membrana citoplasmática afetando a permeabilidade celular e permitindo que a droga entre na célula precipitando seu citoplasma. 
Devido ao caráter catiônico a clorexidina tem forte afinidade por ânions, tais como os íons fosfato da parede celular da microbiota oral que normalmente coloniza as superfícies dentais (HUGO \& LONGWORTH, 1966) reduzindo assim a habilidade de aderência e colonização das superfícies dentais. Provavelmente este é o efeito antiplaca mais significante da clorexidina (AXELSSON, 1973).

ROLLA \& MELSEN (1975), analisaram in vitro a ligação da clorexidina com diversos componentes orgânicos e inorgânicos presentes na saliva, tais como: grupos carboxílicos, sulfatos, fosfatos e extratos protéicos das glândulas salivares maiores. Sabendo-se que cátions bivalentes podem desalojar a clorexidina de grupos fosfatos e grupos carboxílicos, os autores sugerem que a substantividade da clorexidina seja explicada pela liberação da mesma advinda dos vários sítios de ligação por meio do cálcio salivar. Outros mecanismos inibidores da placa são citados, a exemplo da redução dos microrganismos disponíveis na saliva e ligações subletais da clorexidina com grupos fosfatos da superfície bacteriana que reduzem a adsorção de bactérias ao dente.

O efeito antimicrobiano da clorexidina foi mostrado contra cepas Gram negativas e positivas, fungos e leveduras, aerobias facultativas e anaeróbias (EMILSSON, 1977). Apesar de ser um agente antimicrobiano de largo espectro, os estreptococos do grupo mutans são mais fortemente afetados que os outros membros da microbiota oral (EMILSSON, 1977; MALTZ-TURKIENICZ et al., 1980). 
A concentração mínima das soluções a base de clorexidina que produz inibição bacteriana é $0,12 \%$. Concentrações inferiores falham em reduzir a contagem de Streptococcus mutans na saliva (CLARK \& GUEST, 1994).

Raramente se considera a possibilidade de interações entre enxaguatórios e dentifrícios (BARKVOLL et al., 1988; BARKVOLL et al., 1989). Como exemplo, o detergente lauril sulfato de sódio (LSS), que é o mais comumente usado em dentifrícios, é incompatível com a clorexidina em soluções aquosas (BONESVOLL, 1977), pois sendo a última um composto catiônico, formará sais de baixa solubilidade com ânions como sulfatos, fosfatos e carboxilatos (ROLLA et al., 1970; ROLLA \& MELSEN, 1975; BARKVOLL et al., 1988). Suspensões contendo ambos apresentam-se, com efeito antimicrobiano reduzido (BARKVOLL et al., 1989). O monofluorfosfato (MFP) também é incompatível com a clorexidina e é uma substância comum em dentifrícios (BARKVOLL et al., 1988). Segundo BARKVOLL et al. (1989), o intervalo minutos recomendado entre o uso do dentifrício e a clorexidina, deve ser superior a 30 ou preferencialmente próximo de 2 horas.

Efeitos colaterais podem ser ocasionados, com o uso clínico da clorexidina (GREENSTEIN et al., 1986). Provavelmente, o bem documentado manchamento dentário é o mais problemático efeito adverso do uso destes produtos orais (NORDBO, 1971).

O gosto desagradável, alterações de paladar ou até mesmo inflamações gengivais são outros efeitos colaterais também relatados como desconfortos BOWDEN, 1996). 
A clorexidina é também utilizada como anti-séptico em feridas, apesar de uma solução a 0,002\% desta droga, mostrar mínima citotoxicidade, ela

é capaz de suprimir a divisão celular humana quase completamente, afetando também a contração do colágeno e a síntese protéica total, implicando, que apesar de ser tida como anti-séptico seguro, o processo de reparo em feridas pode ser atrapalhado (PUCHER \& DANIEL, 1992).

\section{I.5. QUITINA / QUITOSANA}

A quitosana é um polímero natural proveniente da reação de desacetilação da quitina, um dos mais abundantes polissacarídeos encontrados na natureza. A quitina é proveniente principalmente de exoesqueletos de moluscos (camarão, caranguejo e lula), sendo um polissacarídeo de cadeia linear constituído por unidades de 2-acetamida-2-deoxi-D-glicopiranose que, a exemplo do que ocorre na celulose com suas unidades de 2-deoxi-D-glicopiranose, são unidas por ligações glicosídicas. A fórmula estrutural da quitina é muito similar à da celulose, exceto que os grupos $(-\mathrm{OH})$ na posição 2 foram substituídos por grupos $\left(-\mathrm{NHCOCH}_{3}\right)$, (Figura 3). A semelhança estrutural é refletida nas funções similares desses polímeros na natureza, onde ambos atuam como material estrutural. 


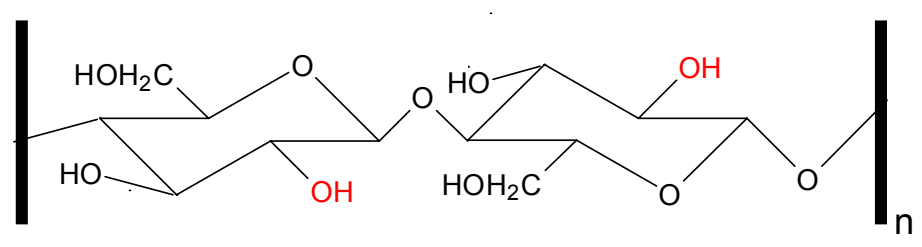

Celulose

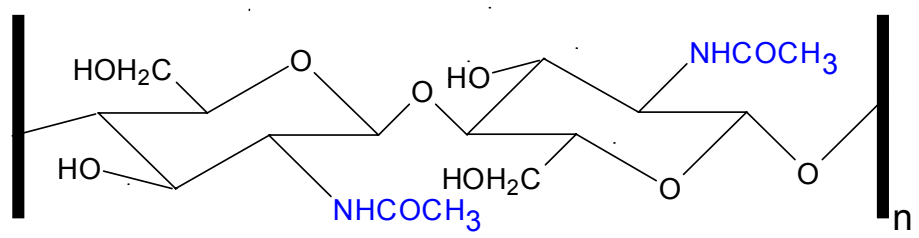

Quitina

FIGURA 3 - Representação esquemática das estruturas de celulose e quitina.

Em 1811, ocorreu a descoberta da quitina em cogumelos, pelo professor francês Henri Braconnot sendo denominada primeiramente como fungina. Odier, em 1823 isolou um resíduo insolúvel de insetos, chamando-o de quitina, sendo este nome derivado da palavra grega "Chiton", que significa carapaça ou caixa protetora. A quitina contém nitrogênio em sua estrutura, o que foi descoberto somente em 1843 por Payen. Rouget descobriu em 1859 a quitosana através da ebulição de uma solução de hidróxido de potássio com quitina, sendo que a quitina é precursora da quitosana, como também sua maior aplicação é na produção da mesma (SHAHIDI, et al, 1999; MAJETI \& KUMAR, 2000; POLYMAR, 2004).

A Tabela 2 mostra as principais fontes naturais de quitina e quitosana. 
Tabela 2: Fontes naturais de quitina e quitosana

\begin{tabular}{||c|c|c||}
\hline Animais Marinhos & Insetos & Microorganismos \\
\hline Anelídios & Escorpiões & Algas Verdes \\
\hline Moluscos & Aranhas & Leveduras \\
\hline Celenterados & Formigas & Fungos \\
\hline Lagosta & Besouros & Esporos \\
\hline Caranguejo & & Algas Marrons \\
\hline "Krill" & & \\
\hline Camarão & & \\
\hline
\end{tabular}

A quitina ocorre em três formas diferentes denominadas $\alpha, \beta$ e $\gamma$, as quais diferem no arranjo de suas cadeias. A forma $\alpha$, encontrada principalmente em crustáceos, insetos e fungos, apresenta um arranjo alternado de cadeias paralelas e antiparalelas. A ocorrência da forma $\beta$ é menos comum, sendo encontrada exclusivamente em organismos marinhos como lulas e algas microscópicas e possui um arranjo de cadeias paralelas. A forma $\gamma$ ainda não foi completamente caracterizada, mas sugeriu-se um arranjo de duas cadeias paralelas e uma antiparalela (ROBERTS,1992; RATHKE \& HUDSON, 1994). A forma $\alpha$ é dominante e mais estável que as outras duas $\beta$ e $\gamma$, mas estas últimas podem ser convertidas à forma $\alpha$ através de tratamentos adequados (SIGNINI, 1998). 
Como citado anteriormente, da reação de desacetilação parcial da quitina obtém-se a quitosana, um polieletrólito catiônico (em meio ácido), que estruturalmente é um polissacarídeo linear com um número variável e randomicamente localizado de grupos $\mathrm{N}$-acetil-glucosamina. Dependendo da fonte e procedimentos de preparação, seu peso molecular médio pode variar entre 50 e $1000 \mathrm{Da}$ e as preparações comerciais tem graus de desacetilação variando entre $50-90 \%$. Uma definição mais moderna de quitina e quitosana é que ambas têm a mesma estrutura química, uma série de copolímeros lineares de 2-acetamino-2-deoxiglicose e 2-amino-2-deoxi-D-glicose. As diferenças residem em que a quitosana é solúvel em solução ácida diluída e a quitina não, e a fronteira entre ambas é o grau de desacetilação, que quando maior que $60 \%$ a quitina passa a ser chamada de quitosana.

Estruturalmente a diferença entre elas é a retirada do grupo acetila da quitina (Figura 4).

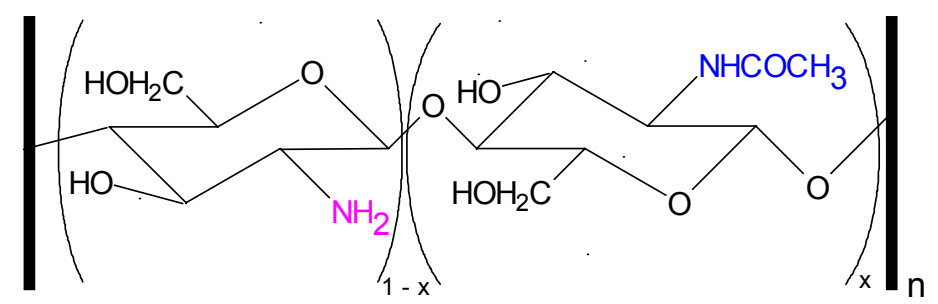

FIGURA 4 - Representação esquemática da estrutura de quitosana, com $x$ representando o grau de acetilação.

O esquema mostrado na figura 5 indica as etapas envolvidas na obtenção e preparação de quitina e quitosana. 


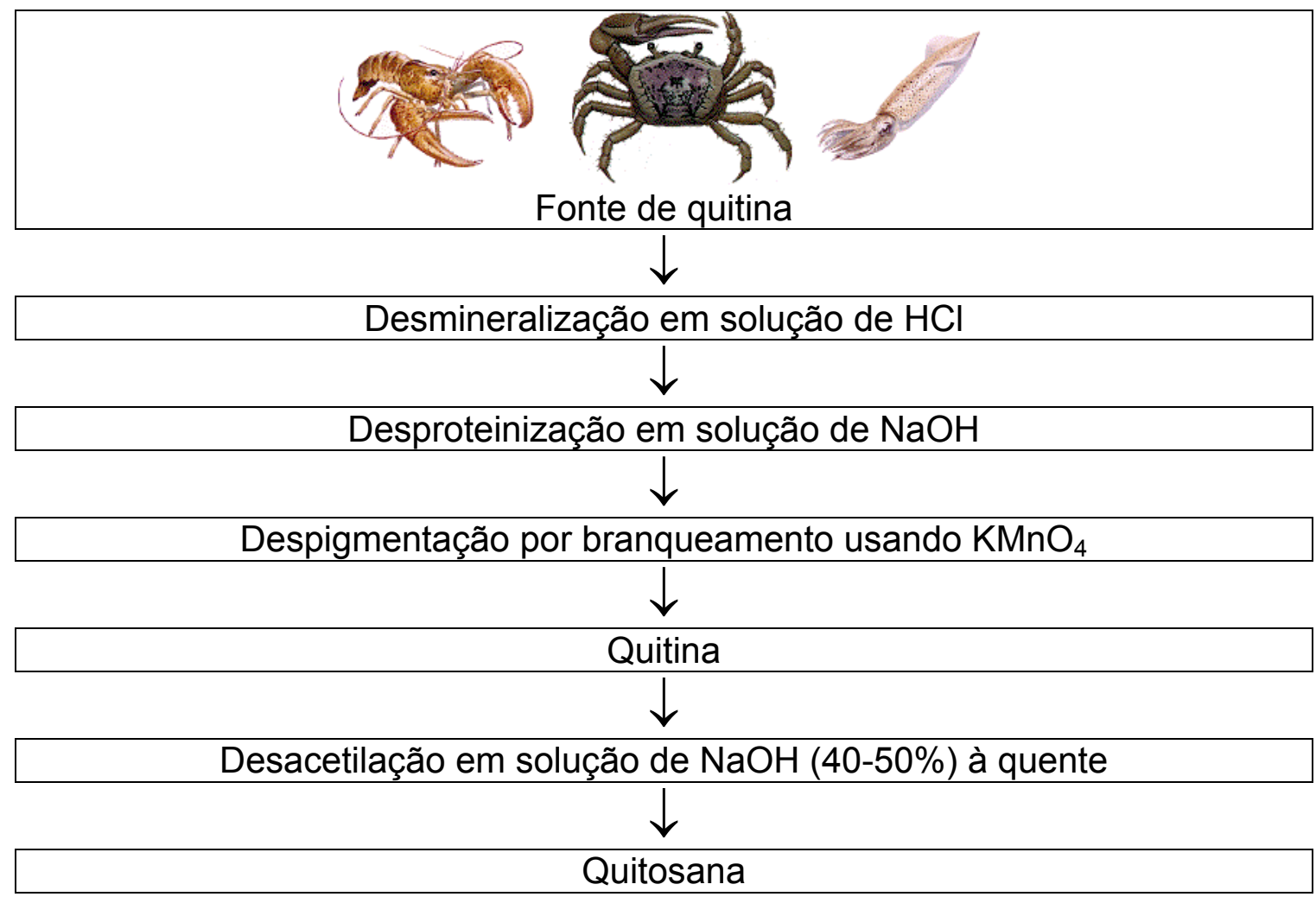

FIGURA 5 - Esquema da obtenção da quitina e quitosana.

Todas as propriedades físico-químicas apresentadas pela quitosana (solubilidade, viscosidade, comportamento polieletrolítico e outros) dependem do grau de acetilação, da distribuição de cargas ao longo da cadeia e da massa molar do polímero, que são propriedades que podem ser controladas durante a reação de desacetilação. As propriedades de retenção de água e a biodegradabilidade da quitosana podem ser controladas também por ligações cruzadas entre suas cadeias.

Nas cadeias de quitosana os átomos de nitrogênio estão na forma, principalmente de grupos amino alifáticos primários e, assim, sofrem reações 
típicas de aminas. Os grupos amino desacetilados, quando protonados $(\mathrm{pH}<6)$, são os responsáveis pelas cargas positivas que tornam a quitosana um policátion.

Os grupos amino estão totalmente protonados em $\mathrm{pH} 3$. Para o caso de poliaminas, quanto maior o número de grupos protonados na cadeia, devido à repulsão eletrostática entre eles, maior será a facilidade de dissociação do ácido conjugado, $\mathrm{R}-\mathrm{NH}_{3}{ }^{+}$, (pois uma vez nessas condições ocorre maior hidrofilicidade, portanto maior absorção de água). Devido à alta densidade de grupos aminos, a quitosana é um bom agente coagulante e floculante, podendo interagir com substâncias carregadas negativamente tais como proteínas, corantes e polímeros.

A quitosana, embora insolúvel em meios aquosos neutro e básico, dissolve-se em ácidos orgânicos (acético, fórmico, lático) ou inorgânicos $(\mathrm{HCl})$, resultando em soluções viscosas. Amostras comerciais geralmente são solúveis somente em soluções aquosas de pH menores que 6,0. A insolubilidade em água das amostras de quitosana pode ser uma vantagem para certas aplicações, mas pode complicar o uso em outras aplicações (como por exemplo, efeitos biológicos em $\mathrm{pH}$ fisiológico).

A versatilidade de poder ser transformada em filmes, membranas, fibras, gel, pasta, tabletes, microesferas, assim como flocos, pó ou soluções tem possibilitado as inúmeras aplicações comerciais, industriais, ambientais e biomédicas da quitosana (SHAHIDI, et al., 1999; MAJETI \& KUMAR, 2000; RABEA, et al., 2003; POLYMAR, 2004; PADETEC, 2004). Há alguns anos, as 
principais aplicações da quitosana eram na remoção de sedimentos de água, quelação de íons metálicos e na indústria de alimentos. Atualmente a quitosana vem sendo bastante utilizada na produção de cosméticos, medicamentos, aditivos alimentícios, membranas semipermeáveis e no desenvolvimento de biomateriais, tanto na medicina como na odontologia.

Há cerca de três décadas a quitosana está sendo usada em processos de purificação de água, principalmente devido à propriedade quelante (remoção de íons metálicos), bem como no tratamento de água para a remoção de óleo.

$\mathrm{Na}$ indústria alimentícia é usada como estabilizante de gordura e aroma, aditivo, preservação e conservação. Em cosméticos a quitosana é empregada em produtos para cuidados da pele devido ao efeito umectante, para cabelos por oferecer proteção e efeito antieletrostático, como também é usada para encapsulamento de fragrâncias, pigmentos e ingredientes ativos (POLYMAR, 2004; PADETEC, 2004).

Na saúde a quitosana vem sendo usada como: agente absorvedor de gorduras, redutora de colesterol, regeneração tecidual (pele, mucosa, ossos), controle de pressão arterial, agente hemostático e antitrombogênico, sistema de liberação de drogas e mais recentemente como agente antimicrobiano.

O uso da quitosana como biomaterial se baseia em suas inúmeras propriedades que são: (SHAHIDI, et al., 1999; MAJETI \& KUMAR, 2000; SHEPHERD, et al., 1997).

a) biocompatibilidade e atoxicidade; 
b) biodegradabilidade (hidrólise enzimática por quitosanase e lisozima);

c) bioadesividade;

d) ser agente bacteriostático e antimicrobiano;

e) apresentar habilidade de acelerar a formação de osteoblastos, responsáveis pela formação do osso;

f) ser agente hemostático;

g) apresentar atividade imunoadjuvante;

h) acelerar o processo de cicatrização de feridas;

i) formar complexos com polieletrólitos aniônicos tais como proteínas, polímeros e outros;

j) ser passível de modificações químicas, podendo se obter derivados com grande variedade de propriedades e aplicações; além de ser também um material que pode ser trabalhado em diversas formas.

\section{I.6. QUITOSANA - EFEITO ANTIMICROBIANO}

A quitosana e oligômeros de quitosana atraem considerável interesse devido a várias propriedades biológicas, como por exemplo: biocompatibilidade (LEE et al., 1995; HIRANO et al., 1988; MUZZARELLI, 1988), biodegradação (SASHIWA et al., 1993), bioreabsorção (NORDTVEIT et al., 1994), bioatividade (MUZZARELLI, 1996). 
O efeito antimicrobiano das soluções de quitosana está sendo observado por vários pesquisadores contra vários fungos e bactérias, sendo este efeito influenciado por diversos fatores, entre eles o tipo de quitosana, o grau de polimerização entre outras propriedades físicas.

Para completa inativação de Staphylococcus aureus após dois dias de incubação, foram necessárias concentrações de quitosana maiores (1-1,5\%) no estudo de WANG (1992). De acordo com CHANG et al. (1989) concentrações de quitosana maiores ou iguais a $0,005 \%$ foram suficientes para o mesmo efeito sobre o mesmo microrganismo.

A completa inativação de Escherichia coli pode ser observada, segundo WANG (1992), com concentrações de quitosana de 0,5 a $1 \%$ após dois dias de incubação, podendo ser alcançada já no primeiro dia se a concentração for maior que $1 \%$.

DARMADJI \& IZUMIMOTO (1994) relatam que concentrações maiores que $0,1 \%$ são necessárias para inibir o crescimento de Escherichia coli e SIMPSON et al. (1997) reportaram ser preciso somente $0,0075 \%$ de quitosana para inibir o crescimento do mesmo microrganismo.

Vários fatores influenciam na atividade antimicrobiana da quitosana e de seus derivados, entretanto os autores são unânimes em relação ao seu potencial como agente antimicrobiano.

O mecanismo das atividades antifúngicas e antimicrobianas da quitosana ainda não está esclarecido, mas acredita-se que estas atividades são originadas da natureza catiônica da quitosana que pode se ligar com os sítios 
aniônicos das proteínas resultando assim numa atividade seletiva sobre fungos e bactérias.

KYOON NO et al. (2002) estudaram seis tipos de quitosana e seis oligômeros de quitosana com diferentes pesos moleculares contra quatro bactérias Gram negativas e sete Gram positivas. Concluíram neste estudo que a quitosana tem maior atividade antibacteriana que os oligômeros, embora o efeito inibitório tenha diferido com o peso molecular para cada bactéria, entretanto a quitosana a $0,1 \%$ de concentração geralmente demonstra maior efeito bactericida contra bactérias Gram positivas que Gram negativas.

Derivados de quitosana com alta porcentagem de cadeias enxertadas, estudadas por XIE et al. (2002), apresentaram melhor solubilidade em água sendo o efeito inibitório destes efetivos contra Staphylococcus aureus e Escherichia coli.

JEON et al. (2001) pesquisaram o efeito antimicrobiano de quitooligossacarídeo com diferentes pesos molecular e demonstraram que com peso molecular maior que $10 \mathrm{KDa}$ a substância foi mais efetiva, inclusive o efeito antimicrobiano foi mais efetivo contra microrganismos patógenos que não patógenos.

ZHENG \& ZHU (2003) verificaram que para a concentração de $1 \%$ de quitosana o peso molecular alto ou baixo não interferiu na atividade antimicrobiana contra Escherichia coli, sendo que para esta concentração obtiveram um efeito bactericida, para o Staphylococcus aureus. Para quitosana com peso molecular menor que 5KDa não foi eficaz em nenhuma das 
concentrações estudadas, mas com o aumento do peso molecular foi verificado o aumento do efeito inibitório, inclusive na menor concentração que testaram.

KYOON NO et al. (2002) testaram seis quitosanas e seis oligômeros de quitosana com diferentes pesos moleculares contra microrganismos isolados de Tofu, através da técnica de difusão em ágar com o uso de discos de papel, sendo que a atividade antimicrobiana contra os microrganismos testados foi maior para a quitosana que para seus oligômeros.

UCHIDA et al. (1989) relataram que quitosana hidrolisada pela quitosanase foi mais efetiva como agente antimicrobiano quando comparada com quitosana nativa e oligômeros de quitosana. $\mathrm{CHO}$ et al. (1998) reportaram que a atividade antimicrobiana da quitosana contra E. coli e Bacillus sp. aumenta com a diminuição da viscosidade da mesma.

SEKIGUCHI et al. (1994) investigaram oligômeros de quitosana com peso molecular entre 2350 e 21600 Da contra várias bactérias e reportaram que o crescimento do Bacillus cereus foi suprimido, em cultura em ágar, com oligômero de quitosana $0,2-0,3 \%$ de concentração com peso molecular de 11000 Da.

SUDARSHAN et al. (1992) testaram glutamato de quitosana e lactato de quitosana contra nove tipos de bactérias dentre elas Salmonella typhimurium, ambos os sais na concentração de $2 \mathrm{gL}^{-1}$. Os resultados indicaram que não existe ação especifica, pois o efeito bactericida foi similar tanto para bactérias Gram positivas como para Gram negativas para os dois sais. 
JUNG et al. (1999) avaliaram o efeito antimicrobiano de amostras de quitosana e de copolímero de quitosana com cadeias enxertadas contra três microrganismos, os resultados deste estudo denotaram que as amostras foram seletivas com melhor efeito antimicrobiano para Candida albicans e Trichophyton violaceum.

Contra odontopatógenos, poucos são os estudos realizados, TARSI et al. (1998) observaram que quitosana e derivados com baixo peso molecular inibem a adesividade do Streptococcus mutans a hidroxiapatita, sendo que a capacidade de colonizar a superfície dos dentes destes microrganismos é um dos fatores ligados a iniciação do processo carioso.

CHOI et al. (2001) usaram quitooligossacarídeo na concentração de $0,1 \%$ contra Actinobacillus actinomycetemcomitans que é um periodontopatógeno e verificaram que a inativação deste microrganismo aumentou com o aumento de tempo de exposição. Como o efeito inibitório para Streptococcus mutans foi bem menor não sendo alterado pelo tempo de exposição, os autores inferiram que este resultado foi devido à baixa concentração que utilizaram.

Outros fatores de relevância devem ser considerados para substâncias que são pesquisadas no intuito de serem utilizadas na cavidade oral, dentre eles: substantividade e bioadesividade

IKINCl et al. (2002) observaram que as formulações de quitosana em gel obtiveram uma maior bioadesividade que as preparadas em filme, verificaram também que a clorexidina incorporada a quitosana não influencia 
nesta propriedade. Em relação ao efeito antimicrobiano as substâncias associadas ou não, foram efetivas contra o Porphyromonas gingivalis.

GIUNCHEDI et al. (2002) verificaram in vivo que a clorexidina associada a quitosana permanece por um período bem maior na cavidade bucal do que quando usada sozinha em bochechos, evidenciando a capacidade das formulações de promover a liberação continuada da clorexidina. A atividade antimicrobiana da associação foi aperfeiçoada, sendo mais expressiva contra Cândida albicans. 


\section{OBJETIVOS}

1. Investigar in vitro a atividade antimicrobiana da quitosana contra Streptococcus mutans e microrganismos totais presentes na saliva.

2. Verificar se as associações entre quitosana e clorexidina potencializam a atividade antimicrobiana nas condições deste estudo. 


\section{MATERIAIS E MÉTODOS}

\section{III.1. MEIOS DE CULTURA}

Os meios de cultura consistem da associação de substâncias que fornecem os nutrientes necessários ao desenvolvimento (cultivo) de microrganismos fora do seu meio natural. Tendo em vista a ampla diversidade metabólica dos microrganismos, existem vários tipos de meios de cultura para satisfazer as variadas exigências nutricionais. Além dos nutrientes é preciso também fornecer condições ambientais favoráveis ao desenvolvimento dos microrganismos, tais como $\mathrm{pH}$, pressão osmótica, umidade, temperatura, atmosfera (aeróbia, microaeróbia ou anaeróbia), dentre outras.

Quanto ao seu estado físico os meios de cultura podem ser classificados em:

sólidos, quando contém agentes solidificantes, principalmente ágar (1 a 2,0 \%); semi-sólidos, quando a quantidade de ágar e ou gelatina é de 0,075 a 0,5\%, dando uma consistência intermediária, de modo a permitir o crescimento de microrganismos em tensões variadas de oxigênio ou a verificação da motilidade e também para conservação de culturas;

líquidos, sem agentes solidificantes, apresentando-se como um caldo, utilizados para ativação das culturas, repiques de microrganismos e provas bioquímicas. 
As preparações líquidas geralmente facilitam o crescimento dos microrganismos, mas se existem vários tipos de microrganismos no material semeado, o reconhecimento dos mesmos fica impossibilitado, sendo assim utilizam-se preparações sólidas, onde são visíveis as diferenças entre as colônias formadas. Utilizam-se preparações sólidas também como meio seletivo, ou seja, meios onde são adicionados substâncias que impedem o crescimento de outros microrganismos, favorecendo assim o isolamento e a obtenção de cultura pura de um microrganismo (SILVA, 1999).

Os meios de cultura podem ainda ser classificados quanto à procedência dos constituintes em:

naturais ou complexos, quando usa ingredientes com composição química não definida, tais como extratos de vegetais (malte, tomate, amido de tubérculos, peptona de soja, etc.) de animais (carne, cérebro, fígado, caseína, etc.) e de microrganismos (levedura)

artificiais, sintéticos ou quimicamente definidos quando a composição química é conhecida (usados para trabalhos de pesquisa) e seus componentes servem para suprir as exigências nutritivas dos microrganismos, em fontes de carbono, nitrogênio, vitaminas, energia, sais minerais, dentre outros, quando são conhecidas as necessidades nutricionais específicas.

Os meios de cultura podem ainda ser classificados quanto à composição química podem ser:

básicos (ou simples) - são aqueles que permitem o crescimento bacteriano sem satisfazer contudo nenhuma exigência em especial (Ex. caldo e ágar simples). 
especiais (ou complexos) quando cumprem com as exigências vitais de determinados microrganismos, como meio de infusão de cérebro e coração, ágar suco de tomate, ágar sangue, meio de Loeffler (com soro bovino), ágar chocolate (agar simples fundido, adicionado de sangue e aquecido a $80^{\circ} \mathrm{C}$ ), Meio de Tarozzi (com fragmento de fígado - para anaeróbios), Meio de Lowenstein, meios Shahidi Ferguson Perfringens (SFP), Triptose Sulfito Ciclosserina (TSC) , BairdParker (com gema de ovo) (meios ricos ou meios enriquecidos com as substâncias citadas), etc..

\section{III.1.1. Preparo dos meios de cultura}

Os meios foram preparados, respeitando-se a quantidade especificada de acordo com as instruções dos respectivos fabricantes, sendo todos os meios utilizados neste estudo preparados da mesma forma, com exceção dos meios ágar-sangue e MSB, pois para o acréscimo das substâncias é necessário esperar-se o resfriamento dos meios a $45-50^{\circ}$ após a autoclavagem.

\section{Preparação}

1. Pesar o meio e colocar em um balão de fundo chato $1000 \mathrm{~mL}$, como por exemplo, 38g do ágar Müeller Hinton.

2. Acrescentar $1000 \mathrm{~mL}$ de água destilada e deionizada, medida com uma proveta.

3. Aquecer agitando freqüentemente e ferver por 1 minuto. 
4. Vedar o balão de fundo chato.

5. Esterilizar em autoclave a $121^{\circ} \mathrm{C}$ por 15 minutos.

6. Distribuir em placas ou em tubos dependendo do meio (sólido ou líquido).

Para preparar o ágar-sangue, preparou-se o ágar Mueller Hinton conforme citado, esfriou-se a $45-50^{\circ} \mathrm{C}$ e adicionou-se assepticamente $5 \%$ de sangue de carneiro desfibrinado estéril, homogeneizou-se e então distribuiu-se em placas estéreis.

O meio MSB foi preparado da mesma forma e para adição de bacitracina e sacarose, esfriou-se a $45-50^{\circ} \mathrm{C}$ o meio $\mathrm{MSB}$, adicionou-se às substâncias citadas, homogeneizou-se para então distribuir em placas.

$\mathrm{O} \mathrm{pH}$ dos meios foi verificado através de fita indicadora de $\mathrm{pH}$ e todos os meios estavam dentro dos parâmetros indicados por seus respectivos fabricantes.

\section{III.1.1.1. Ágar Müeller Hinton ${ }^{1}$}

O meio de Ágar Müeller Hinton foi utilizado para os testes de difusão em ágar, por apresentar boa reprodutibilidade nos testes e por suportar o crescimento da maioria dos microrganismos (exceto para Streptococcus), como

\footnotetext{
${ }^{1}$ Biobrás
} 
também foi utilizado para a preparação do ágar sangue (TRABULSI \& ALTERTHUM, 2004). Sua composição é mostrada na tabela 3.

Tabela 3: Composição do Ágar Müeller Hinton

\begin{tabular}{|lc|}
\hline Hidrolisado ácido de caseína & $17,5 \mathrm{~g}$ \\
\hline Extrato de carne & $2,0 \mathrm{~g}$ \\
\hline Amido de batata & $1,5 \mathrm{~g}$ \\
\hline Agar bacteriológico & $17,0 \mathrm{~g}$ \\
\hline Água destilada e deionizada & $1000 \mathrm{~mL}$ \\
\hline
\end{tabular}

\section{III.1.1.2. Ágar sangue}

Sua abundante base nutritiva oferece condições ótimas para a maioria dos microorganismos sendo que o sangue de carneiro desfibrinado é o mais adequado para ser adicionado por não conter anticoagulantes, nem agentes complexantes, fatores imunológicos e outras substâncias que possam interferir no desenvolvimento dos microrganismos (SILVA, 1999). A composição deste meio de cultura não seletivo é mostrada na tabela 4. Este meio foi utilizado para a quantificação dos microorganismos totais presentes na saliva expostos ou não às soluções testadas, como também para os testes de difusão em Agar, onde os Streptococcus mutans crescem adequadamente devido a suplementação com o sangue de carneiro desfibrinado (TRABULSI \& ALTERTHUM,2004). 
Tabela 4: Composição do agar sangue

\begin{tabular}{|lr|}
\hline Sangue de carneiro desfibrinado e estéril $^{2}$ & $5 \%$ \\
\hline Ágar Müeller Hinton & $38 \mathrm{~g}$ \\
\hline Água destilada e deionizada & $1000 \mathrm{~mL}$ \\
\hline
\end{tabular}

\section{III.1.1.3. Brain Heart Infusion ${ }^{3}$ (BHI)}

Meio líquido adequado para o cultivo de bactérias exigentes ou não, utilizado neste estudo para propagação de Streptococcus mutans e para os testes de atividade.

O meio $\mathrm{BHI}$, cuja composição está na tabela 5 , foi distribuído $(5 \mathrm{~mL})$ em tubos de ensaio $15 \times 100 \mathrm{~mm}$.

Tabela 5: Composição do Brain Heart Infusion.

\begin{tabular}{|lc|}
\hline $\mathrm{NaCl}$ & $5,0 \mathrm{~g}$ \\
\hline Dextrose & $2,0 \mathrm{~g}$ \\
\hline Fosfato de sódio & $2,5 \mathrm{~g}$ \\
\hline $\mathrm{BHI}$ & $17,5 \mathrm{~g}$ \\
\hline Peptona de carne & $5,0 \mathrm{~g}$ \\
\hline Peptona de caseína & $5,0 \mathrm{~g}$ \\
\hline Água destilada e deionizada & $1000 \mathrm{~mL}$ \\
\hline
\end{tabular}

\footnotetext{
${ }^{2}$ Biotério Boa Vista

${ }^{3}$ Difco Co
} 


\section{III.1.1.4. Ágar Mitis Salivarius ${ }^{4}$ com bacitracina (MSB)}

O meio MSB (tabela 6) foi usado para obtenção de cultura pura de estreptococcos do grupo mutans, como também para quantificação, pois acrescido de bacitracina ${ }^{5} 400 \mathrm{UL}^{-1}$ e sacarose ${ }^{6} 15 \%$ é seletivo para Streptococcus mutans (GOLD, et al., 1973).

Tabela 6: Composição do Agar Mitis Salivarius

\begin{tabular}{|lc|}
\hline Digerido pancreático de caseína & $6,0 \mathrm{~g}$ \\
\hline Peptona de proteose $\mathrm{n}^{\circ} 3$ & $9,0 \mathrm{~g}$ \\
\hline Peptona de proteose & $5,0 \mathrm{~g}$ \\
\hline Dextrose & $1,0 \mathrm{~g}$ \\
\hline Sacarose & $50,0 \mathrm{~g}$ \\
\hline Fosfato dipotássico & $4,0 \mathrm{~g}$ \\
\hline Azul de tripano & $0,075 \mathrm{~g}$ \\
\hline Cristal violeta & $0,0008 \mathrm{~g}$ \\
\hline Ágar & $15,0 \mathrm{~g}$ \\
\hline Água destilada e deionizada & $1000 \mathrm{~mL}$ \\
\hline
\end{tabular}

\footnotetext{
${ }^{4}$ Merck do Brasil

${ }^{5}$ Difco Co

${ }^{6}$ Sigma Co
} 


\section{III.1.1.5. Letheen Broth ${ }^{7}$ (LB)}

O meio líquido Letheen Broth (Tabela 7) oferece condições nutricionais adequadas para a maioria dos microganismos, foi usado para os testes de atividade e para análise da densidade óptica, distribuído em tubos de ensaio ( 3 e $5 \mathrm{~mL})$ e em tubos tipo Falcon $(10 \mathrm{~mL})$ descartáveis com tampa rosqueável.

Tabela 7: Composição do Letheen Broth

\begin{tabular}{|lc|}
\hline Peptona & $10,0 \mathrm{~g}$ \\
\hline Extrato de carne & $5,0 \mathrm{~g}$ \\
\hline Lecitina & $0,7 \mathrm{~g}$ \\
\hline Tween 80 & $5,0 \mathrm{~g}$ \\
\hline Cloreto de sódio & $5,0 \mathrm{~g}$ \\
\hline Água destilada e deionizada & $1000 \mathrm{~mL}$ \\
\hline
\end{tabular}

\section{III.2. PREPARO DAS SOLUÇÕES}

\section{Solução de Clorexidina a 0,12 e 0,06\%}

As soluções de clorexidina foram preparadas a partir de digluconato de clorexidina $20 \%^{8}$ em solução aquosa, adicionando-se água destilada e estéril até a obtenção da concentração desejada.

\footnotetext{
${ }^{7}$ Difco Co
} 


\section{Soluções de quitosana}

As soluções de quitosana foram preparadas por dissolução de quitosana em acido acético $1 \%$, sob agitação constante e à temperatura ambiente. Inicialmente preparou-se uma solução de quitosana $1 \%$ e pela adição controlada de $\mathrm{NaOH} 0,010 \mathrm{~L}^{-1} \mathrm{~mol}$ foram preparadas soluções em diferentes pHs: 3,$5 ; 4,0 ; 4,5$ e 5,0 . A solução de quitosana $(\mathrm{pH} 5,0)$ foi também preparada nas concentrações 0,$1 ; 0,5 ; 1,0$ e 1,5\%. Utilizou-se quitosana comercial Fluka, com grau de acetilação $76 \%$ e massa molar $400000 \mathrm{gmol}^{-1}$, com valores confirmados por análise de $H^{1} R M N$ e espectroscopia de absorção no infravermelho (TONHI, 1999).

\section{Soluções de quitosana / clorexidina}

As soluções de quitosana / clorexidina foram preparadas pela adição de clorexidina nas concentrações de $0,06 \%$ e $0,12 \%$, ás soluções de quitosana, à pH 5,0.

\section{III.3. CARACTERIZAÇÃO DA QUITOSANA / CLOREXIDINA}

As amostras de quitosana e quitosana/clorexidina foram caracterizadas, com o auxílio da aluna de iniciação científica Rafaela Basso

\footnotetext{
${ }^{8}$ Henrifarma
} 
Montoro, por espectroscopia de absorção na região do infravermelho (FT-IR), análise térmica (TG/DTG e DSC) e microscopia eletrônica de varredura (MEV).

Para a realização das análises foram preparados filmes por evaporação do solvente. Os filmes foram preparados a partir de solução de quitosana na concentração $1 \%(\mathrm{~m} / \mathrm{m})$ utilizando-se ácido acético na concentração de $1 \%(\mathrm{pH}=2,98-\mathrm{pH}$-metro Micronal B-374), sob agitação constante e à temperatura ambiente de aproximadamente $25^{\circ} \mathrm{C}$. As bolhas de ar formadas durante a agitação foram retiradas a vácuo. Para a incorporação de clorexidina, o digluconato de clorexidina foi adicionado na concentração $0,12 \%$ $(\mathrm{m} / \mathrm{m})$ e os filmes foram secos na estufa à temperatura de $60^{\circ} \mathrm{C}$ por 24 horas.

\section{Espectrometria de Absorção no Infravermelho (IV)}

Os espectros de absorção na região do infravermelho foram obtidos em um Espectrofotômetro Bomem ND-120 (FTIR) no intervalo de 400$4000 \mathrm{~cm}^{-1}$, com resolução de $4 \mathrm{~cm}^{-1}$. Todas as soluções foram pipetadas em um suporte de silício $(\mathrm{Si})$ e secas sob fluxo de ar à temperatura ambiente para serem analisadas.

\section{Microscopia Eletrônica de Varredura (MEV)}

Para a realização das análises foram preparadas soluções de quitosana na concentração de $0,1 \%(\mathrm{v} / \mathrm{v})$ pela dissolução de quitosana em 
soluções aquosas de ácido acético $1 \%$, sob agitação constante e à temperatura ambiente. Para a incorporação de clorexidina, o digluconato de clorexidina foi adicionado na concentração $0,12 \%(\mathrm{~m} / \mathrm{m})$. Volumes de $12 \mathrm{~mL}$ das soluções de quitosana foram adicionadas em moldes de Policloreto de Vinila (PVC) de 5,0 x $5,0 \times 0,6 \mathrm{~cm}$ e em seguida foram congeladas de maneira gradativa, como descrito a seguir: em refrigerador por $8 \mathrm{~h}$ a $-2,5^{\circ} \mathrm{C}$, em freezer por $12 \mathrm{~h}$ a $-15^{\circ} \mathrm{C}$ e finalmente em $\mathrm{N}_{2(l)}$ sendo posteriormente submetidas à liofilização. A liofilização foi feita em um equipamento Freezer Dryer, Edwards High Vacuum International/ Model Serial, com bomba a vácuo modelo E2-M8. Após liofilização os materiais foram colocados em dessecador na presença de pastilhas de $\mathrm{NaOH}$.

As fotomicrografias das matrizes de quitosana foram obtidas de sua superfície e de sua região transversal, de modo a se observar a morfologia interna e externa. As matrizes foram cortadas e fixadas em suportes de alumínio, sendo posteriormente recobertas com uma camada de ouro de $30 \mathrm{~nm}$ em um metalizador Balsers modelo SDC 050. Usou-se um microscópio eletrônico de varredura da marca ZEISS, modelo LEO-440, operando com um feixe de elétrons secundário de $20 \mathrm{keV}$ para as análises.

\section{Análise Térmica}

\section{Calorimetria Exploratória Diferencial (DSC)}

Amostras de aproximadamente $10 \mathrm{mg}$ das diferentes matrizes foram colocadas em porta amostra de alumínio não hermético e um segundo 
porta amostra vazio foi utilizado como referência. As medidas foram realizadas na razão de aquecimento de $10^{\circ} \mathrm{C} \cdot \mathrm{min}^{-1}$ em atmosfera dinâmica de $\mathrm{N}_{2}$ $\left(80 \mathrm{~mL} \cdot \mathrm{min}^{-1}\right)$ e na faixa de temperatura de 10 a $550^{\circ} \mathrm{C}$. Usou-se um equipamento da TA Instruments, DSC modelo 2010.

\section{Análise termogravimétrica (TG/DTG)}

Amostras de aproximadamente $10 \mathrm{mg}$ das matrizes foram colocadas em suportes de platina e as medidas foram realizadas na razão de aquecimento de $10^{\circ} \mathrm{C} \cdot \mathrm{min}^{-1}$, em atmosfera dinâmica de $\mathrm{N}_{2}\left(90 \mathrm{~mL} \cdot \mathrm{min}^{-1}\right)$ em um intervalo de temperatura de 10 a $800^{\circ} \mathrm{C}$. Usou-se um equipamento da TA Instruments, TGA modelo 2050.

\section{III.4. PREPARO DAS AMOSTRAS}

\section{III.4.1. Saliva}

Para todos os testes no decorrer deste estudo, amostra de saliva estimulada (através da mastigação de parafina sólida) foi colhida em coletor $^{9}$ estéril, no período da tarde (após o almoço), três horas após a escovação e diluída 100 e 1000 vezes em solução salina estéril $\left(\mathrm{NaCl}(P . A)^{10} 85 \mathrm{gL}^{-1} \mathrm{em}\right.$ água destilada e deionizada), sendo esta utilizada para contagem de microorganismos

\footnotetext{
${ }^{9}$ Bioplass

${ }^{10}$ Synth
} 
totais, como também para verificar-se presença ou ausência de turvação dos meios líquidos.

Os períodos de incubação para todas as técnicas (exceto para a análise da densidade ótica) foram de 48 horas em condições de microaerofilia e mais 24 horas em condições de aerobiose.

\section{III.4.2. Streptococcus mutans}

Para obtenção de cultura pura de estreptococcos do grupo mutans, a amostra de saliva diluída foi inoculada em placas contendo o meio MSB que foram posteriormente incubadas por 48 horas em condições de microaerofilia.

A propagação da cepa foi realizada em $5 \mathrm{~mL}$ de $\mathrm{BHI}$ e a partir deste

meio foi cultivada em Ágar sangue (mesmas condições de incubação). Células microbianas (Streptococcus mutans) foram suspensas em solução salina estéril. Para se realizar os testes de atividade a suspensão foi ajustada de acordo com o grau turbidez do tubo № 1 da Escala de Mac Farland na concentração aproximada de $3 \times 10^{6} \mathrm{cel} \cdot \mathrm{mL}^{-1}$ (ANEXO 1).

Para os testes em que a contagem dos Streptococcus mutans foi necessária, amostras de saliva foram inoculadas nos meio MSB incubadas por 48 horas em condições de microaerofilia, sendo este também o período de incubação para os testes de atividade.

A figura 6 mostra o esquema de preparo das amostras. 


\section{PREPARO DO MATERIAL}

- coleta do material por estimulação - parafina sólida

- diluição da saliva em solução salina estéril ( 1:100 e 1:1000)

- plaqueamento da solução 1:100 (ágar sangue) e 1:1000

( ágar sangue e MSB)

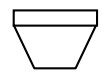

Coletor estéril

Saliva estimulada

( parafina sólida)

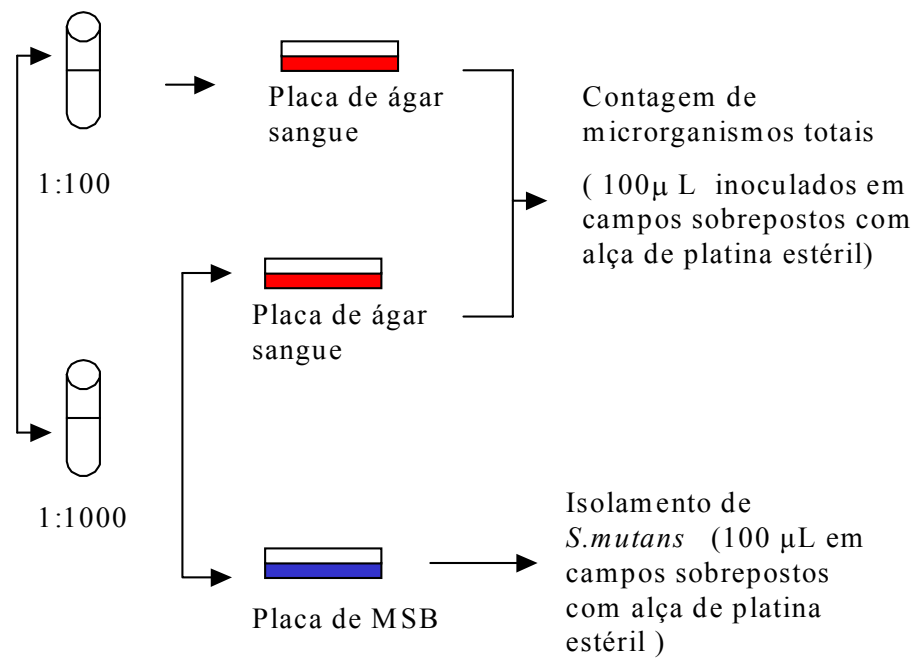

Os meios de cultura foram incubados por $48 \mathrm{~h}$ à $37^{\circ}$ em condições de microaerofilia, o meio ágar sangue foi incubado por mais $24 \mathrm{~h}$ à $37^{\circ} \mathrm{em}$ condições de aerofilia.

FIGURA 6- Preparo das amostras estudadas. 


\section{III.5. TESTES PRELIMINARES}

\section{III.5.1. TESTES DE SENSIBILIDADE}

Amostra de saliva diluída (1000 vezes) foram inoculadas em placas de Petri contendo Ágar Müeller Hinton e de Streptococcus mutans (ajustada ao tubo № 1 da Escala de Mac Farland) foram inoculadas em placas de Petri contendo ágar sangue.

Após o preparo das placas, foram distribuídos em pontos eqüidistantes sobre cada placa (método de difusão em ágar), quatro discos blanck ${ }^{11}$ embebidos com $40 \mu \mathrm{L}$ cada, com as seguintes soluções: quitosana $1 \%$ (nos pHs 3,$5 ; 4,0 ; 4,5$ e 5,0 ), clorexidina $0,12 \%$, quitosana $1 \%$ + clorexidina $0,06 \%$ e quitosana + clorexidina $0,12 \%$.

Com o objetivo de verificar a difusão das soluções testadas em ágar, realizou-se também outra técnica, que consistiu em perfurar quatro poços $(4 \times 4 \mathrm{~mm})$ em pontos eqüidistantes sobre as placas preparadas, aos quais adicionou-se a quantidade padronizada de $50 \mu \mathrm{L}$ de cada uma das soluções testadas nos discos Blanck (discos de papel estéreis), nas condições de incubação citadas anteriormente.

\footnotetext{
${ }^{11}$ Cefar
} 


\section{III.5.2. TESTES DE CONTATO DIRETO}

As amostras de saliva diluídas (1000 vezes) foram pipetadas e inoculadas com auxilio de cabo Kholi e alça de inoculação esterilizada (alíquotas de $20 \mu \mathrm{L}$ ) em placas de Petri contendo os meios MSB e Ágar sangue.

Em cada placa foram pipetadas e espalhadas uniformemente (mesma alíquota) as soluções testadas.

Primeiramente testou-se o comportamento de soluções de quitosana $1 \%$ em diferentes pHs: 3,$5 ; 4,0 ; 4,5$ e 5,0.

Após a avaliação dos diversos pHs, avaliou-se soluções de quitosana ( $\mathrm{pH} 5,0)$ em diversas concentrações, que foram: 0,$1 ; 0,5 ; 1,0$ e 1,5\%.

Posteriormente foram analisadas soluções de quitosana nas concentrações citadas associadas a clorexidina nas concentrações de 0,06 e $0,12 \%$, como também somente à clorexidina na concentração de $0,12 \%$.

Todos os testes foram feitos em triplicata, inclusive o que se usou para o controle (sem inoculação das soluções testadas).

A figura 7 ilustra a representação esquemática da técnica utilizada no teste de contato direto. 


\section{TESTE DE CONTATO DIRETO}

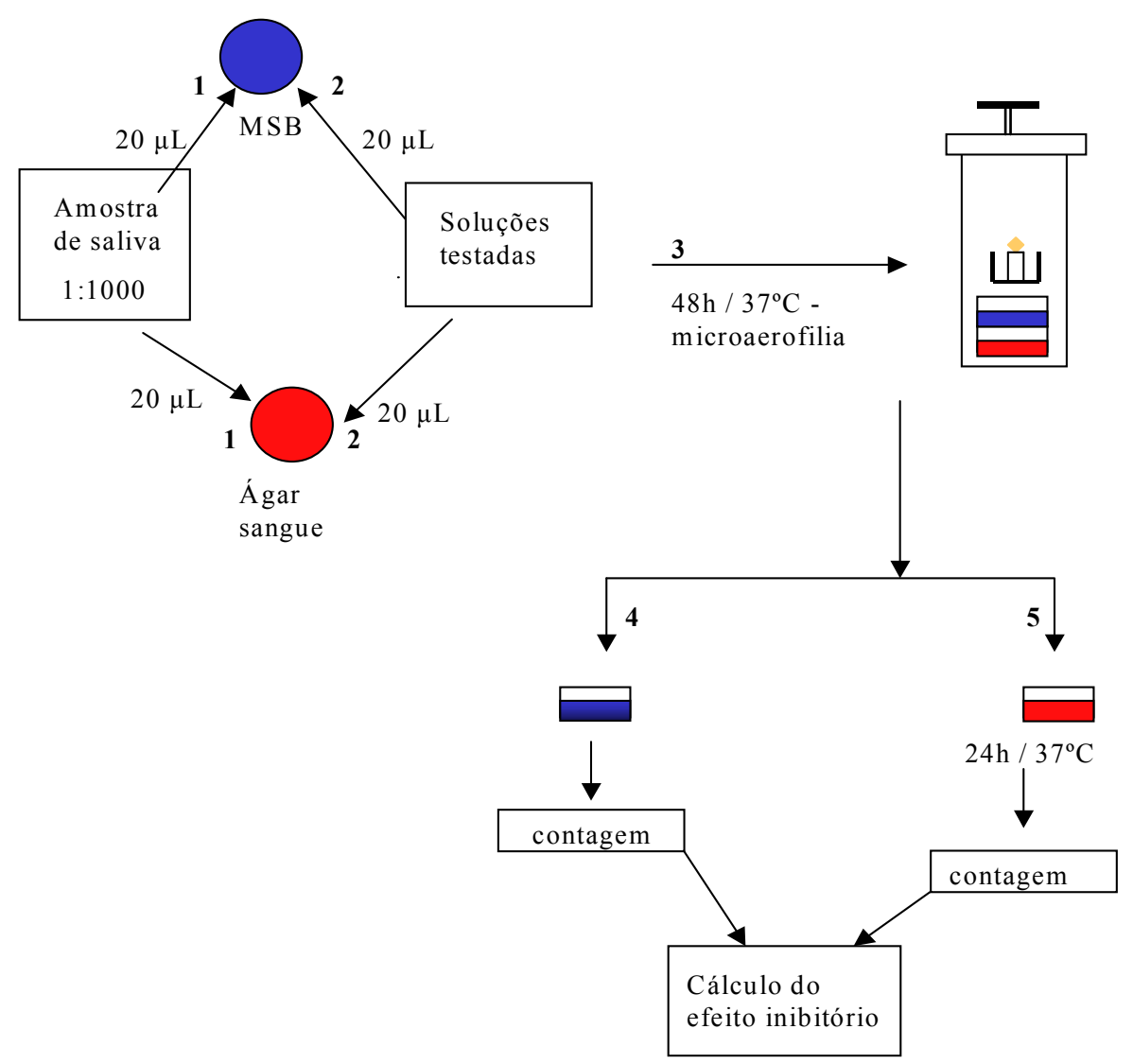

FIGURA 7. Representação esquemática da técnica utilizada no teste de contato direto. 
Após estes procedimentos todas as placas foram incubadas nas condições estabelecidas, as placas de MSB foram quantificadas primeiramente enquanto as placas de Ágar sangue permaneciam incubadas, para posterior quantificação.

Após a contagem direta das UFC (unidades formadoras de colônia), ou seja, a quantificação, calculou-se a média aritmética de cada uma das condições estudadas, pois os testes foram realizados em triplicata.

O cálculo do efeito inibitório foi feito utilizando-se a equação:

$\eta=\frac{N 1-N 2}{N 1} \quad X 100 \%$

Sendo:

$\eta=$ efeito inibitório

N1 = média aritmética das UFC das placas controle (sem solução)

N2 = média aritmética das UFC de cada uma das soluções testadas.

\section{III.6. ANÁLISE DA DENSIDADE ÓPTICA}

Das amostras preparadas, com auxílio de cabo Kholi e alça de inoculação, foi colhida uma alçada de cada amostra (Streptococcus mutans e população total bacteriana presente na saliva) e inoculadas em $3 \mathrm{~mL}$ de Letheen Broth e incubadas durante 12 horas. 
Posteriormente $200 \mu \mathrm{L}$ de cada cultura foram transferidos para 5 tubos do tipo Falcon, contendo $10 \mathrm{~mL}$ de LB, perfazendo um total de 10 tubos com cultura. Adicionou-se mesma alíquota $(200 \mu \mathrm{L})$ das soluções de quitosana nas respectivas concentrações: $0,1 \%, 0,5 \%, 1,0 \%$ e $1,5 \%$. O controle positivo foi 1 tubo de cada amostra, onde não foi inoculada nenhuma das soluções testadas.

O controle negativo foi realizado através da inoculação das soluções de quitosana citadas. Para que o total líquido fosse igual em todos os tubos, acresceu-se $200 \mu \mathrm{L}$ do meio utilizado aos tubos dos controles.

A distribuição dos tubos é mostrada na tabela 8.

Preparados os tubos, todos foram incubados a $37^{\circ} \mathrm{C}$ sob agitação constante de 200rpm em aparelho incubador ShacKer ${ }^{12}$. Em intervalos de 1 hora a densidade óptica foi medida para a amostra de saliva (controle positivo) esperando até que atingisse a D.O. de aproximadamente 0,8 (fase exponencial, ou seja, quando a população dobra a cada geração) o qual ocorreu após 4 horas. Após isto foi realizada a análise da D.O. dos tubos com saliva. Utilizou-se um espectrofotômetro ${ }^{13}$ de luz visível, com comprimento de onda de $600 \mathrm{~nm}$

Os tubos com amostra de Streptococcus mutans continuaram incubados, pois se verificou um crescimento mais lento e a D.O. foi medida a intervalos de 4 horas, sendo atingida a mesma densidade após o período de 48 horas, procedendo-se da mesma forma, ou seja, os tubos com amostra de $S$. mutans foram submetidos à análise da D.O.

\footnotetext{
${ }^{12}$ Tecnal

${ }^{13}$ Amershan Pharmacia Biotech
} 
Os tubos de controle negativo permaneceram incubados pelo mesmo período que os tubos com amostra de Streptococcus mutans e como houve necessidade de confirmação de resultados para este grupo, alíquotas de $200 \mu \mathrm{L}$ foram inoculadas em placas contendo o meio ágar sangue com a finalidade de se verificar possíveis bactérias contaminantes nas soluções de quitosana.

Tabela 8:Distribuição dos tubos

\begin{tabular}{l|l|l}
\hline Tubos (10 mL LB) & Cultura & Substâncias \\
\hline 1 & saliva & quitosana $0,1 \%$ \\
\hline 2 & saliva & quitosana $0,5 \%$ \\
\hline 3 & saliva & quitosana $1,0 \%$ \\
\hline 4 & saliva & quitosana $1,5 \%$ \\
\hline $5+200 \mu \mathrm{l} \mathrm{LB}$ & saliva & +++ \\
\hline 6 & S. mutans & quitosana $0,1 \%$ \\
\hline 7 & S. mutans & quitosana $0,5 \%$ \\
\hline 8 & S. mutans & quitosana $1,0 \%$ \\
\hline 9 & S. mutans & quitosana $1,5 \%$ \\
\hline $10+200 \mu \mathrm{l}$ LB & S. mutans & +++ \\
\hline $11+200 \mu \mathrm{l}$ LB & --- & quitosana $0,1 \%$ \\
\hline $12+200 \mu \mathrm{l}$ LB & --- & quitosana $0,5 \%$ \\
\hline $13+200 \mu \mathrm{l}$ LB & --- & quitosana $1,0 \%$ \\
\hline $14+200 \mu \mathrm{l}$ LB & --- & quitosana $1,5 \%$ \\
\hline$(+++)$ Controle positivo sem adição das substâncias testadas \\
$(--)$ Controle negativo sem adição de cultura.
\end{tabular}




\section{III.7. TESTES DE ATIVIDADE}

As amostras teste foram preparadas em $5 \mathrm{~mL}$ de solução salina estéril. Para Streptococcus mutans a amostra teste foi ajustada ao tubo № 1 da Escala de Mac Farland e a amostra da saliva foi preparada na diluição de 1000 vezes.

Objetivando os testes de atividade, cento e vinte cones de papel absorventes de № $40^{14}$ (28 mm comprimento e $0,4 \mathrm{~mm}$ de diâmetro), foram esterilizados por autoclavagem e imersos nas amostras teste durante três minutos, visando o processo de contaminação. Decorrido este período, cones de papel foram distribuídos em placas de Petri contendo $10 \mathrm{~mL}$ das diferentes soluções analisadas, considerando-se os quatro períodos de tempo estudados e o grupo controle.

A intervalo de 2, 3, 4 e 30 minutos, os cento e vinte cones de papel absorventes foram removidos do contato com as soluções analisadas e transportados individualmente para $5 \mathrm{~mL}$ de Letheen Broth.

Decorridas as 48 horas de incubação (microaerofilia), os tubos com amostra teste de estreptococcos do grupo mutans foram então analisados macroscopicamente. Quanto à presença ou ausência de turvação, indicativa ou não de crescimento de microorganismos, enquanto os tubos com amostra de saliva permaneciam por mais 24 horas incubados em condições de aerobiose

\footnotetext{
${ }^{14}$ Tanari
} 
para então serem analisados. Foram empregados dois grupos controles, um negativo e um positivo. $O$ controle negativo foi feito com $5,0 \mathrm{~mL}$ de Letheen Broth, enquanto o controle positivo foi realizado com $0,1 \mathrm{~mL}$ das amostras testadas em 5,0 $\mathrm{mL}$ de Letheen Broth para poder analisar se as amostras utilizadas no experimento estavam viáveis ou não.

A figura 8 mostra o esquema do teste de atividade.

Todos os tubos foram selecionados para a confirmação dos resultados macroscópicos. Assim, 0,1 $\mathrm{mL}$ do inóculo obtido a partir do Letheen Broth foi transferido para $5 \mathrm{~mL}$ de $\mathrm{BHI}$ sob as mesmas condições de incubação. A leitura final foi também macroscópica e, em caso de dúvida, complementada pela observação microscópica tendo como parâmetro a coloração de Gram (ANEXO 2). Os testes foram realizados em triplicata e a confirmação dos resultados procedeu-se da mesma forma.

\section{III.8. TESTES DE SIMULAÇÃO DE BOCHECHO}

Amostra de $1 \mathrm{~mL}$ saliva diluída (1000 vezes) foram pipetadas em tubos de ensaio $(10 \times 75 \mathrm{~mm})$, sendo adicionado a seguir $(1 \mathrm{~mL})$ a cada tubo uma das soluções de quitosana, nas quatro concentrações citadas.

Com o objetivo de fazer uma simulação de bochechos homogeneizou-se a mistura, com auxílio de micropipetador ${ }^{15}$ durante um minuto e inoculou-se alíquotas de $20 \mu \mathrm{L}$ em placas de Petri, contendo os meios MSB e

\footnotetext{
${ }^{15}$ Micropipetedor Mecânico Mellini
} 
ágar sangue, decorridos os tempos de 1, 2, 3, 4 e 5 minutos. A figura 9 mostra a representação esquemática da simulação de bochecho.

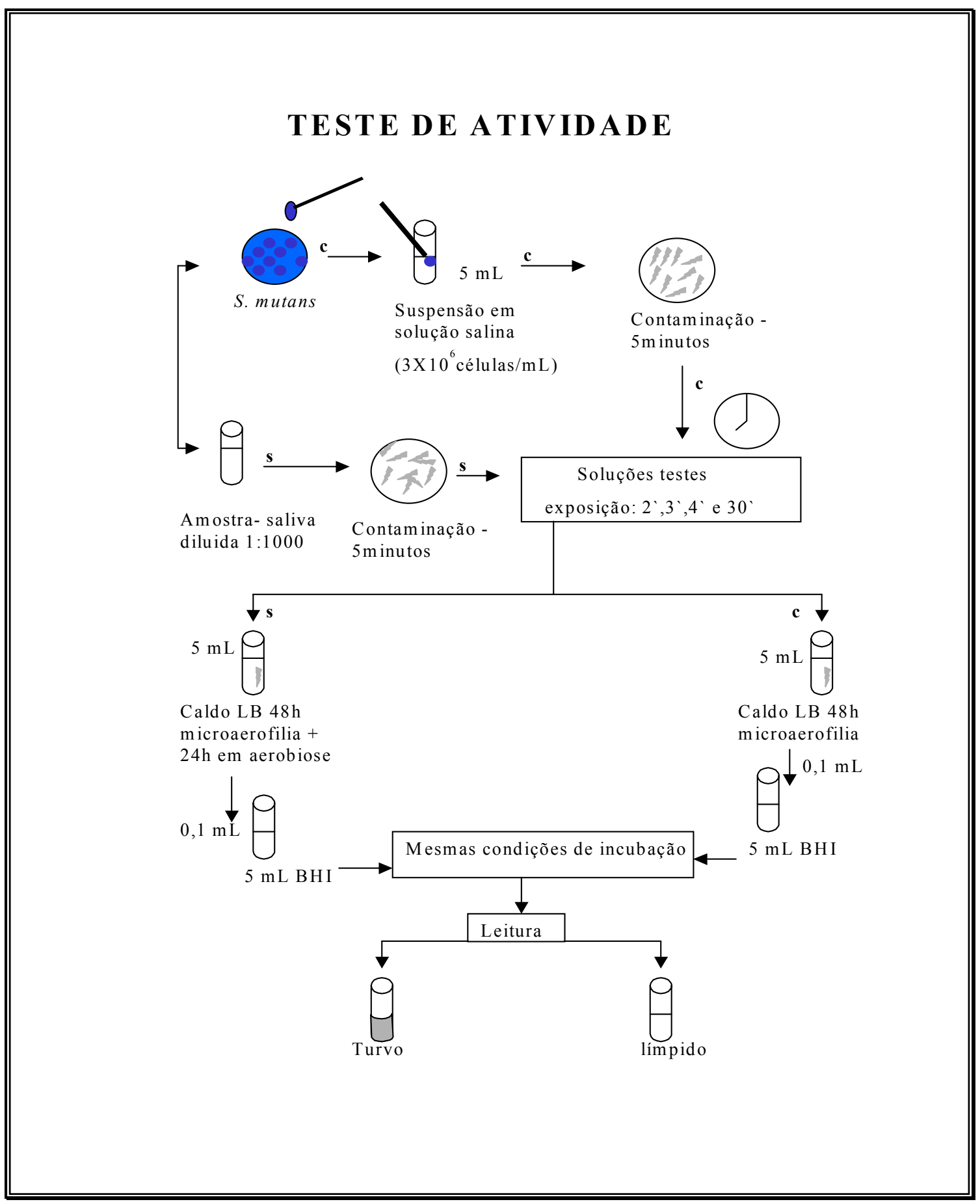

FIGURA 8- Esquema da técnica utilizada nos testes de atividade. 


\section{TESTE DE SIMULAÇÃO DE BOCHECHO}

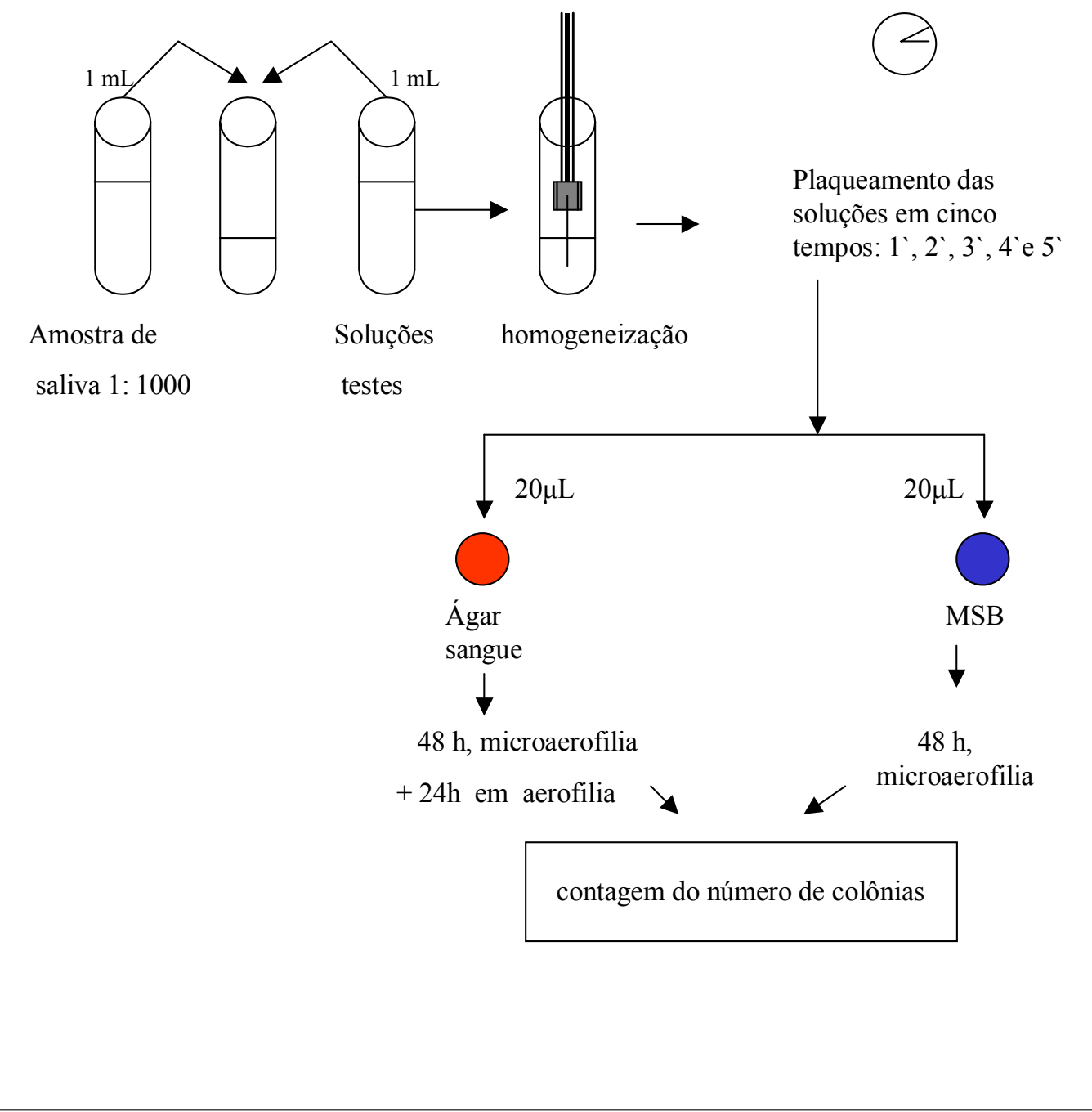

FIGURA 9- Esquema do teste de simulação de bochechos. 
Para comparação e controle do teste, foram adicionadas à amostra (mesma alíquota) solução de clorexidina $0,12 \%$ e solução salina estéril respectivamente sob as mesmas condições.

Após os períodos e as condições de incubação citados, as UFC foram quantificadas e o efeito inibitório foi calculado como anteriormente. 


\section{RESULTADOS E DISCUSSÃO}

\section{IV.1.CARACTERIZAÇÃO}

A Figura 10 mostra os espectros de absorção na região do infravermelho para as matrizes de quitosana e quitosana após a incorporação de clorexidina na concentração de $0,12 \%(\mathrm{~m} / \mathrm{m})$. Observa-se que no espectro da quitosana sem incorporação da droga os picos encontrados estão em 3365, 2916 e 2879,1647 e $1377 \mathrm{~cm}^{-1}$ que são atribuídos à presença de grupos - $\mathrm{OH}$, $\mathrm{CH}_{2}$ e $-\mathrm{CH}_{3}$ (grupos alifáticos), grupos $-\mathrm{C}=\mathrm{O}$ e estiramento $-\mathrm{C}-\mathrm{O}$ do grupo alcoólico primário, respectivamente. Comparando se o espectro de infravermelho obtido da quitosana em presença de clorexidina com o espectro da clorexidina pura encontrado na literatura, tem-se que as bandas da clorexidina estão presentes $\left(1636,1559,1492,1411,1252,825 \mathrm{~cm}^{-1}\right)$ indicando que a clorexidina foi incorporada à quitosana. Essas bandas encontram-se um pouco deslocadas frente ao espectro da clorexidina pura. 


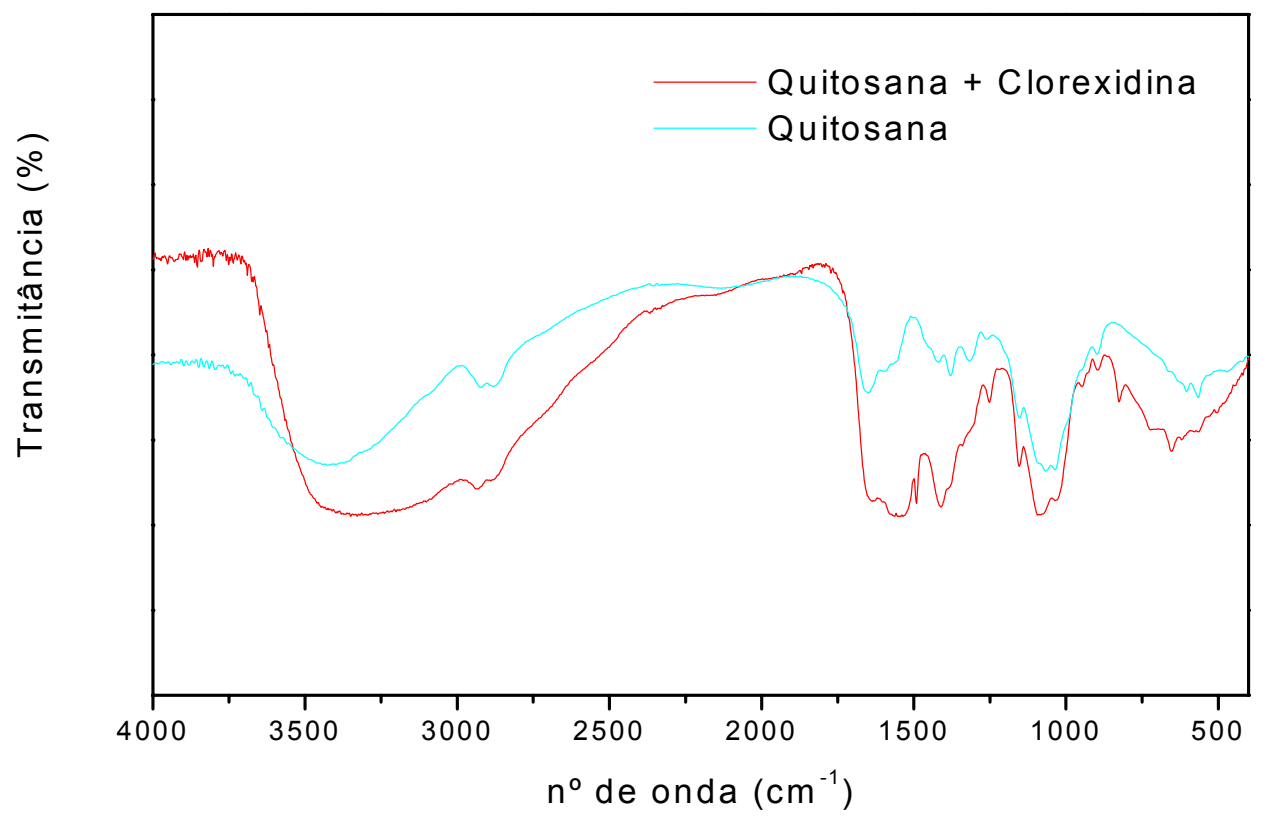

FIGURA 10- Espectro de absorção na região do infravermelho para membranas de quitosana e quitosana com clorexidina.

As Figuras 11 e 12 mostram as curvas DSC para as matrizes de quitosana e quitosana/clorexidina obtidas em atmosfera de nitrogênio e atmosfera de ar sintético. Observa-se que a presença de clorexidina na matriz não altera significativamente o padrão de comportamento térmico da quitosana. Observa-se à presença de um pico endotérmico próximo de $110^{\circ} \mathrm{C}$ que pode ser atribuído á presença de água no material. A degradação térmica ocorre acima de $270^{\circ} \mathrm{C}$. A presença de clorexidina no material pode ser comprovada pelo aparecimento de um pequeno pico endotérmico próximo de $142^{\circ} \mathrm{C}$ (Figura 12), que é compatível com o valor observado para a temperatura de fusão da clorexidina $142,9^{\circ} \mathrm{C}$ (Figura 13). 


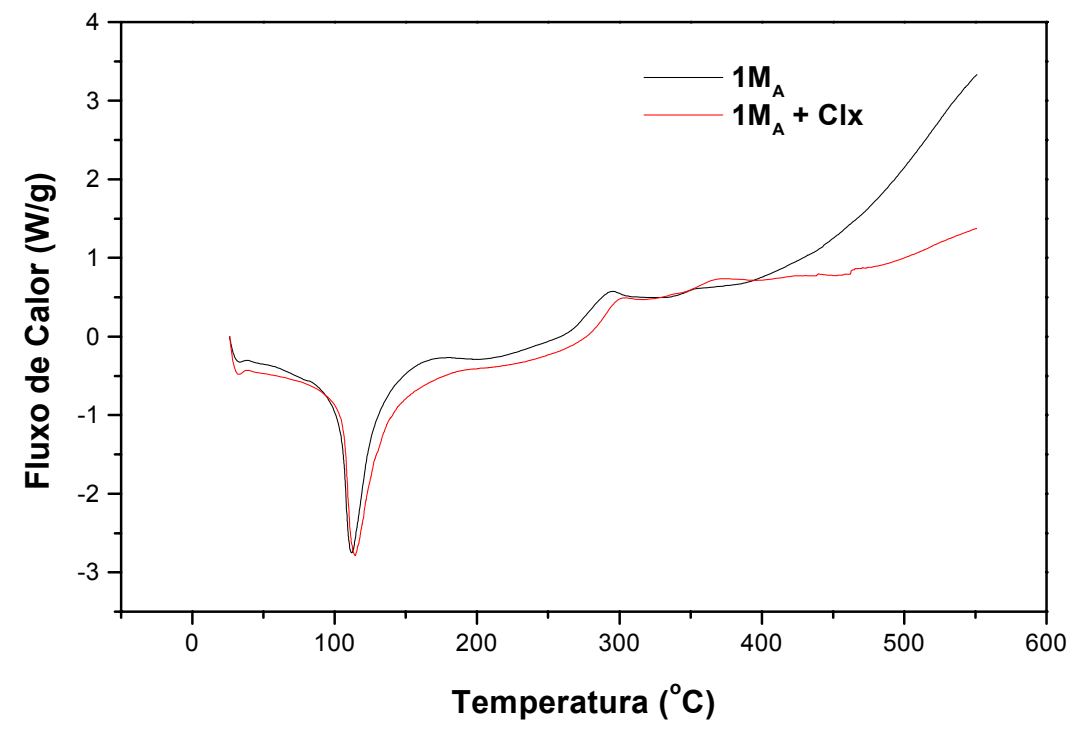

FIGURA 11- Curvas DSC de Quitosana $\left(1 \mathrm{M}_{\mathrm{A}}\right)$ e Quitosana com Clorexidina $\left(\mathrm{N}_{2}\right)$

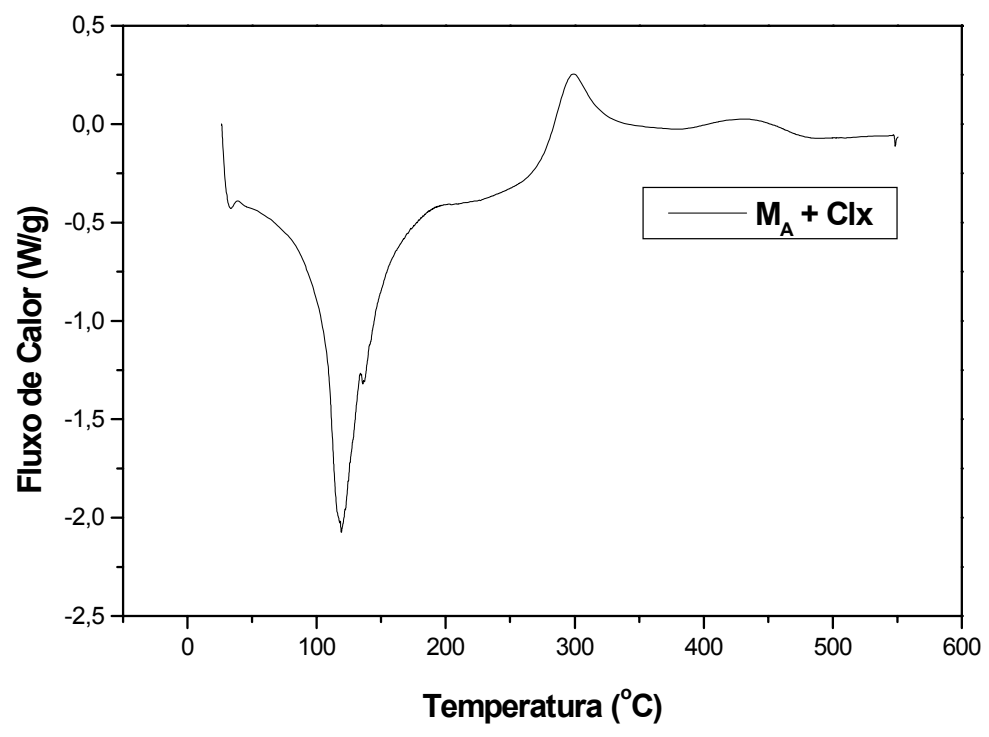

FIGURA 12 - Curva DSC de quitosana com clorexidina (ar). 


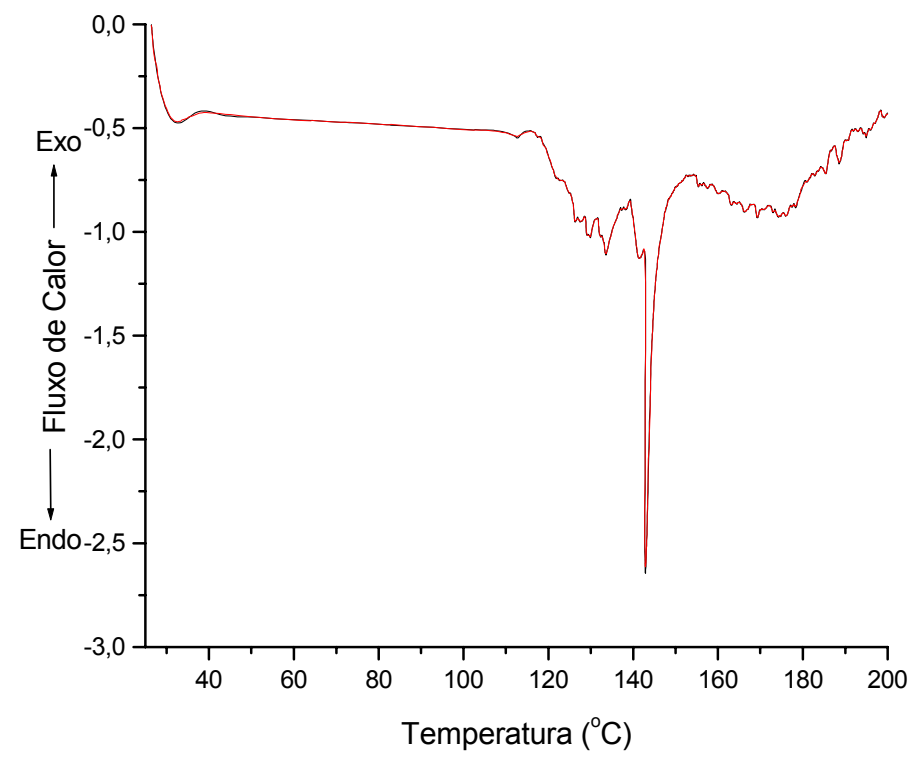

FIGURA 13- Curva DSC para a clorexidina (ar)

A Figura 14 mostra as curvas termogravimétricas obtidas em atmosfera de ar e nitrogênio para a matriz contendo $0,12 \%$ de clorexidina incorporada e para a matriz de quitosana em ar. É possível observar que a presença da clorexidina torna a matriz menos estável iniciando-se a decomposição em torno de $150^{\circ} \mathrm{C}$, o que explicaria o pequeno pico observado na figura 12, que poderia ser indicativo da presença de clorexidina na matriz. As diferenças observadas após $450^{\circ} \mathrm{C}$ se devem á queima incompleta do material orgânico quando em atmosfera inerte.

A quitosana exibe o comportamento típico reportado para este polissacarídeo decompondo-se em dois estágios. O primeiro pico na curva da derivada termogravimétrica com máximo em $106,3^{\circ} \mathrm{C}$ está associado à perda de peso de 9,97 \% devido à liberação de água. O segundo estágio inicia em 
$258,3^{\circ} \mathrm{C}$, com máximo em $300,1^{\circ} \mathrm{C}$, esta associado à perda de peso de $44,49 \%$ devido à liberação de material das unidades acetiladas e não acetiladas do polímero. Pela análise térmica de quitosana com diferentes graus de acetilação ficou bem estabelecido que o efeito térmico que ocorre em aproximadamente a $310{ }^{\circ} \mathrm{C}$ nas curvas termogravimétrica e DSC são fortemente dependentes do grau de acetilação, desenvolvendo-se a partir daí um método empírico para determinação do grau de acetilação Os resultados de TG estão bem correlacionados com os dados obtidos por calorimetria exploratória diferencial.

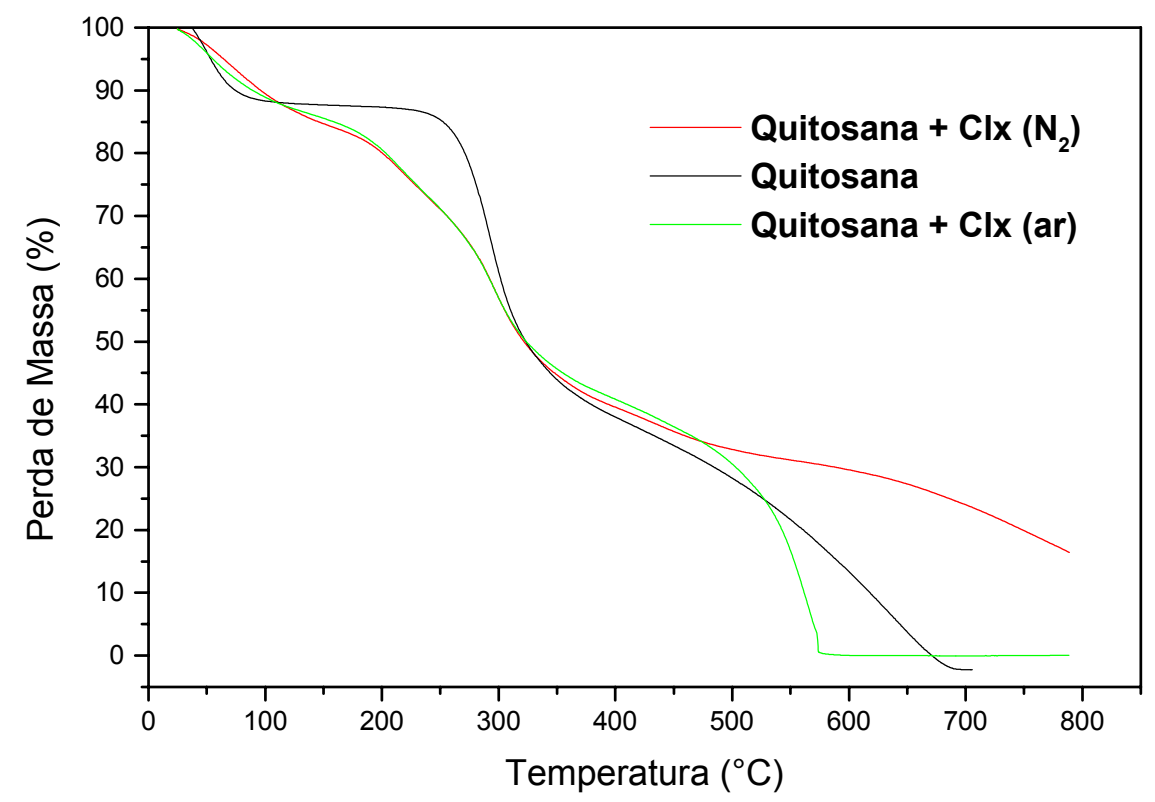

FIGURA 14 - Curva TG para as matrizes de Quitosana, Quitosana com Clorexidina $\left(\mathrm{N}_{2}\right)$ e Quitosana com Clorexidina (ar).

As Fig. 15 e 16 mostram as fotomicrografias obtidas da superfície das matrizes com aumentos de 200 e 1000 vezes. 

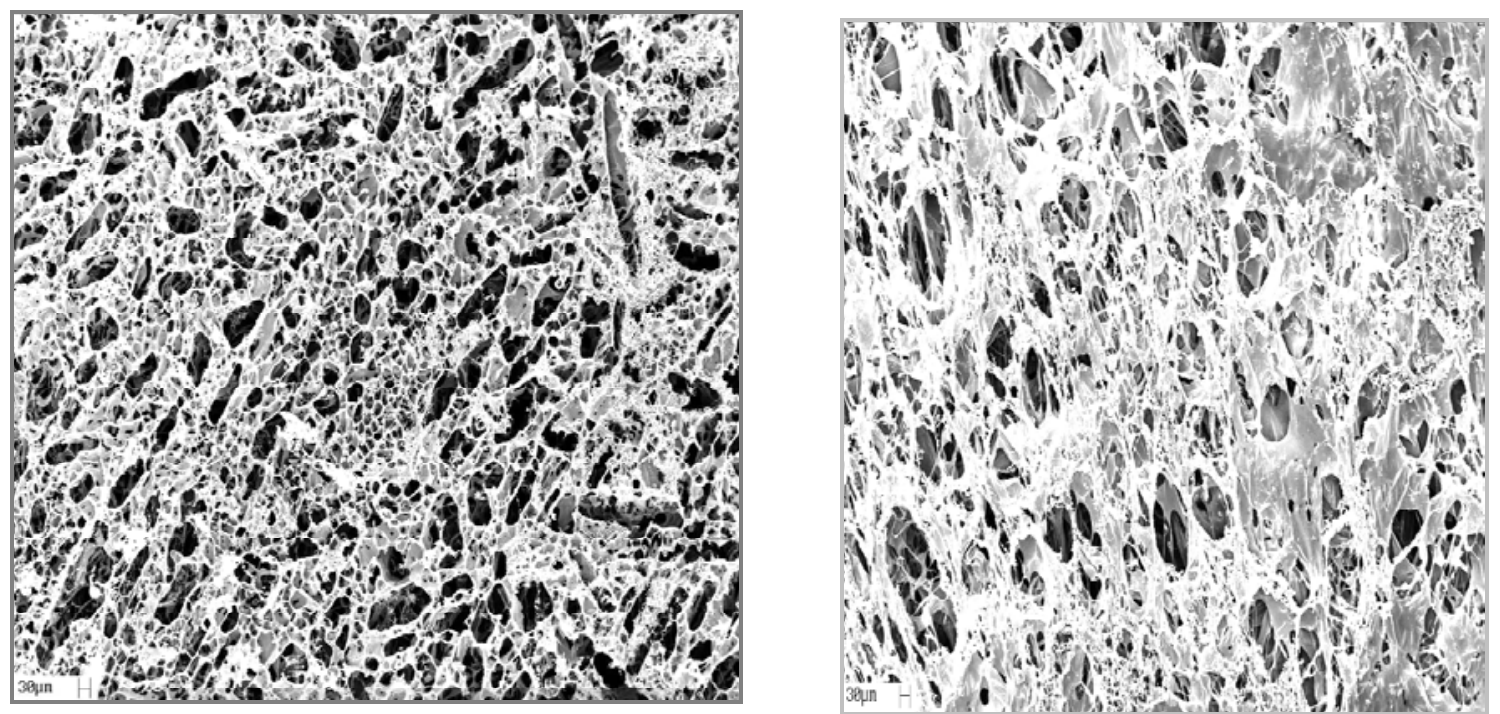

FIGURA 15 - Fotomicrografias da superfície das matrizes de quitosana 0,1\%, preparadas com ácido acético 1\% (aumento de 200 vezes).

A- quitosana B- quitosana/clorexidina
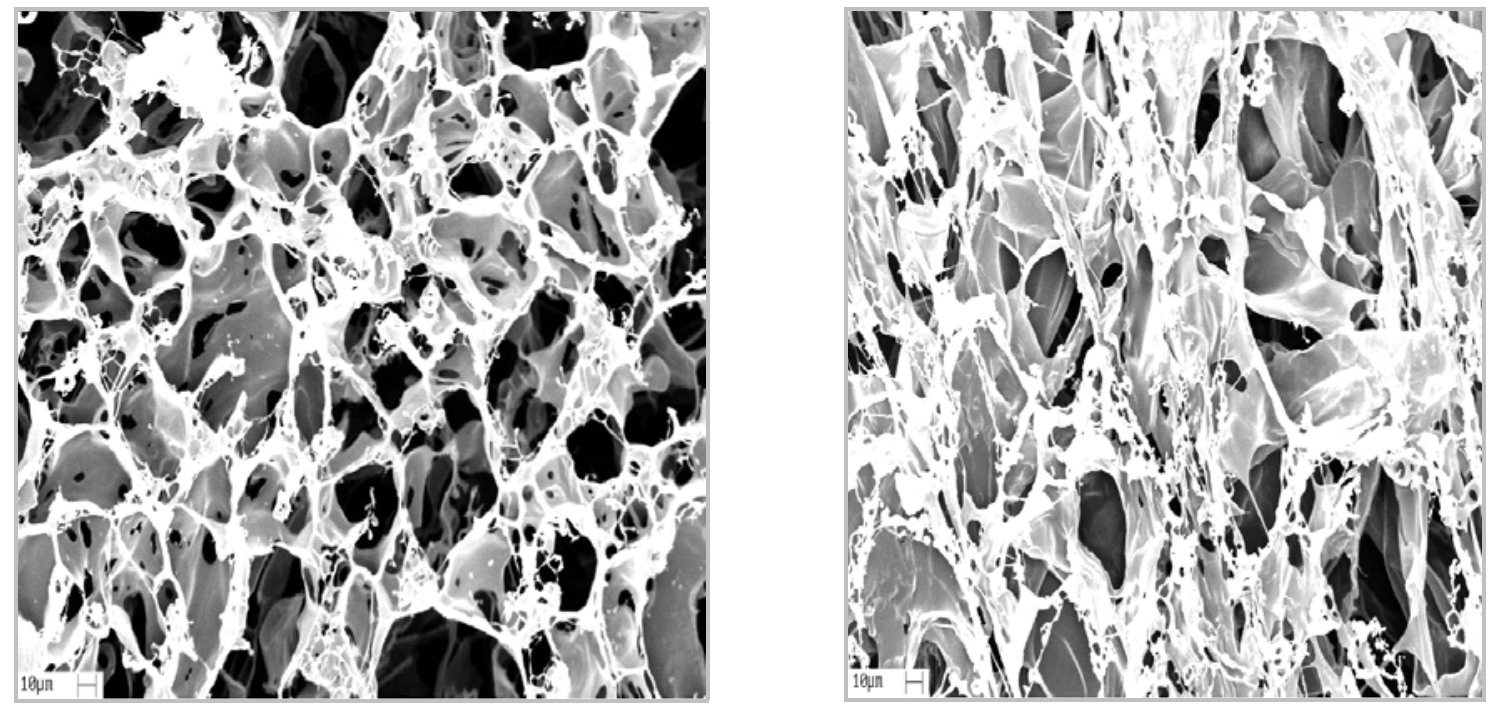

FIGURA 16 - Fotomicrografias da superfície das matrizes de quitosana 0,1\%, preparadas com ácido acético $1 \%$ (aumento de 1000 vezes). A- quitosana B- quitosana/clorexidina 
As matrizes de quitosana com ou sem clorexidina preparadas pela dissolução em ácido acético 1\% são morfologicamente diferentes. A matriz de quitosana possui poros distribuídos aleatoriamente e com certo grau de conectividade entre eles. Na matriz de Quitosana/Clorexidina observa-se um emaranhado sobre os interstícios, podendo-se sugerir essa atribuição à presença de clorexidina incorporada.

\section{IV.2. AMOSTRAS E SOLUÇÕES}

A contagem de microrganismos presentes na saliva foi escolhida como nicho representativo por ser apontada como principal método utilizado para a quantificação de Streptococcus mutans (DASANAYAKE, et al., 1995), existindo uma relação direta entre seu número e o número de sítios intra-orais colonizados (TOGELIUS, et al., 1984; DASANAYAKE, et al., 1995)

A eficácia das soluções testadas foi escolhida, pois a quantificação dos Streptococcus mutans na saliva está associada com a cárie dentária e o biofilme bacteriano (GIBBONS \& van HOUTE, 1975; LOESCHE, et al., 1975; DASANAYAKE, 1995; BOWDEN, 1996). A redução das bactérias presentes na saliva tem sido relacionada com o controle e a prevenção de doenças orais (ZICKERT, et al. 1983; GISSELSSON, et al., 1988; LINDQUIST, et al., 1989; ISOKANGAS, et al., 1991; BOWDEN, 1996).

Um único doador foi utilizado neste estudo, para que se tornasse viável a quantidade dos testes realizados. Como GOLD (1973) preconizou uma 
média de colonização $\left(0,25 \times 10^{3}\right.$ ufc/mL) de Streptococcus mutans no cultivo da saliva em MSB e RAMACCIATO (2000) constatou que a média preconizada foi verificada em todos os voluntários (30) de seu estudo sobre o efeito antimicrobiano de diversas soluções. Dado o exposto, como o doador apresentou esta média pode-se inferir que os resultados obtidos seriam condizentes com outros doadores.

As figuras 17 e 18 mostram, respectivamente várias UFC de microrganismos presentes na saliva (flora normal) diluída de um indivíduo, e Streptococcus mutans isolados da amostra de saliva em MSB (GOLD 1973).

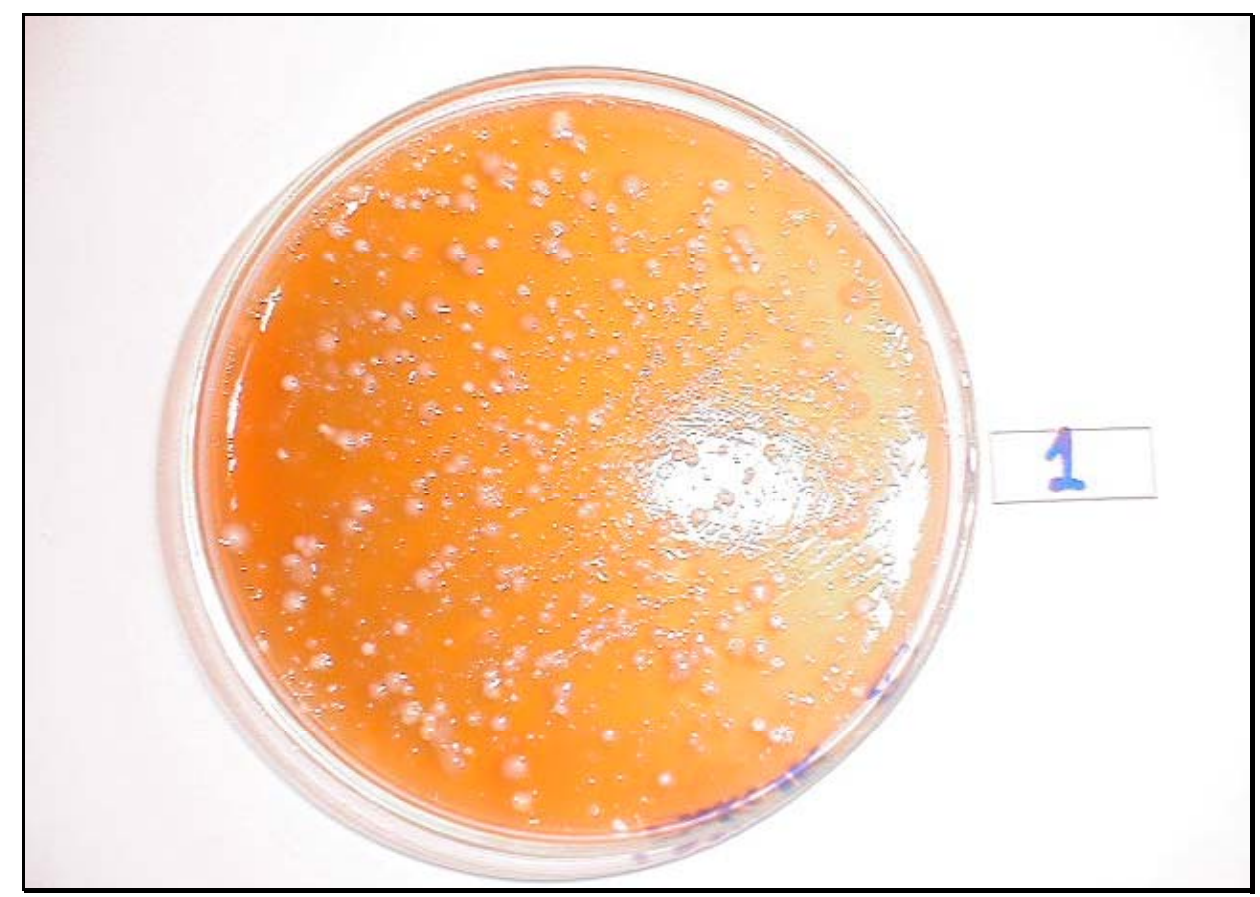

FIGURA 17- Microrganismos totais, amostra de saliva cultivada em ágar sangue, após 72 horas de incubação. 


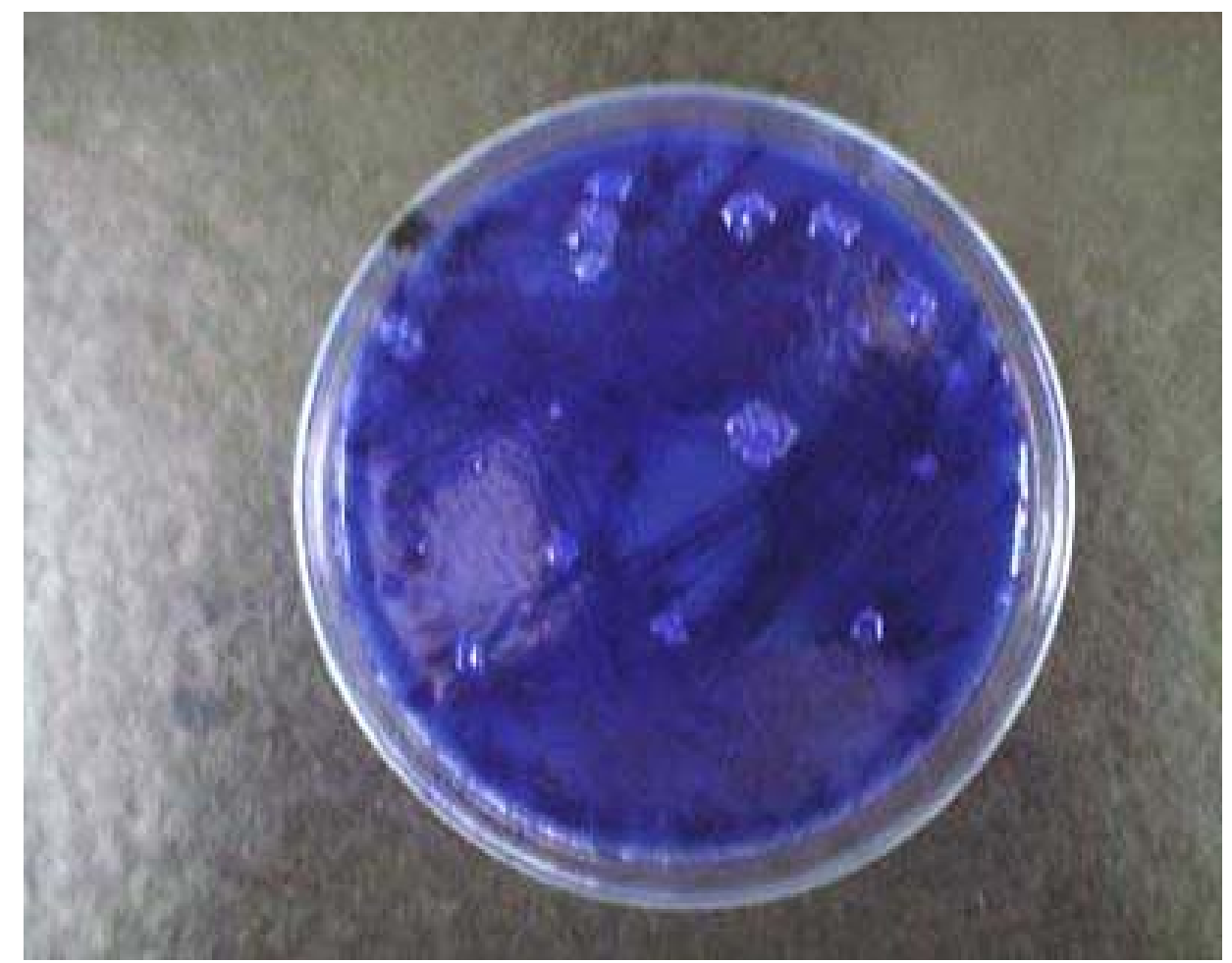

FIGURA 18- Amostra de saliva em MSB, isolamento de Streptococcus mutans, após 48 horas de incubação.

Devido à incompatibilidade da clorexidina com o detergente lauril sulfato de sódio (KIRKGAARD, et al., 1974; ROLLA, et al.,1970; ROLLA \& MELSEN, 1975; BONESVOLL, 1977; BARKVOLL, et al.,1988) presente em todos os dentrifícios, a coleta da saliva foi realizada 3 horas após a escovação.

Dentre as várias concentrações utilizadas para a clorexidina, a de 0,12\% usada para bochechos únicos e diários já mostrou ser eficaz (CLARK \& GUEST, 1994). Sendo assim, é justificável o uso da mesma como parâmetro de comparação com as soluções estudadas bem como a associação desta substância com a quitosana. 
O efeito antimicrobiano das soluções de quitosana está sendo estudado por vários pesquisadores, inclusive as variáveis que afetam este efeito, dentre elas: a concentração, o pH, o grau de acetilação e peso molecular.

Neste estudo, devido às controvérsias a respeito do grau de acetilação e peso molecular, foi utilizada quitosana comercial Fluka, com grau de desacetilação $76 \%$ e massa molar $400000 \mathrm{gmol}^{-1}$ e variou-se $\circ \mathrm{pH}$ nos testes preliminares e concentração em todos os testes.

\section{IV.3. TESTES PRELIMINARES}

\section{IV.3.1. Testes de sensibilidade}

Esta metodologia possibilita a avaliação qualitativa da sensibilidade do microrganismo à substância a ser testada, caracterizando os microrganismos em sensíveis, intermediários ou resistentes às substâncias testadas. Com a difusão da substância nos meios de cultura, presente nos discos ou nos poços previamente perfurados nos meios de cultura, forma-se zonas de inibição ao redor das substâncias se os microrganismos tem o crescimento inibido.

O meio de cultura recomendado é o ágar Mueller Hinton por apresentar boa reprodutibilidade nos testes e baixa concentração de inibidores bem como por suportar o crescimento da maioria dos microrganismos. Os Streptococcus não crescem adequadamente neste meio e necessitam da 
suplementação com $5 \%$ de sangue de carneiro desfibrinado para o emprego da técnica.

Com relação ao método de difusão em ágar, o tamanho da zona de inibição microbiana depende da solubilidade e da difusibilidade da substância testada e, portanto, pode não expressar efetivamente todo o seu potencial.

O teste de sensibilidade a antimicrobianos através do método de difusão em ágar foi ineficaz nas condições deste estudo (observar figura19), pois a quitosana, a clorexidina e a associação entre elas, não apresentaram zonas de inibição em nenhuma das duas formas estudadas (disco blanck para teste de sensibilidade e perfuração de poços, com acréscimo das soluções aos mesmos), fato este que não é condizente com os estudos de KYOON NO, et al. (2002) que obtiveram resultados qualitativos bastante significantes através do uso do mesmo teste em relação ao efeito antimicrobiano da quitosana e oligômeros de quitosana contra microrganismos isolados de tofu.

A discrepância entre os resultados pode estar relacionada com os diferentes microrganismos alvo dos estudos ou mesmo com o pH das soluções pois os autores citados trabalharam com soluções de quitosanas e oligômeros de quitosana no $\mathrm{pH}$ 5,9. 


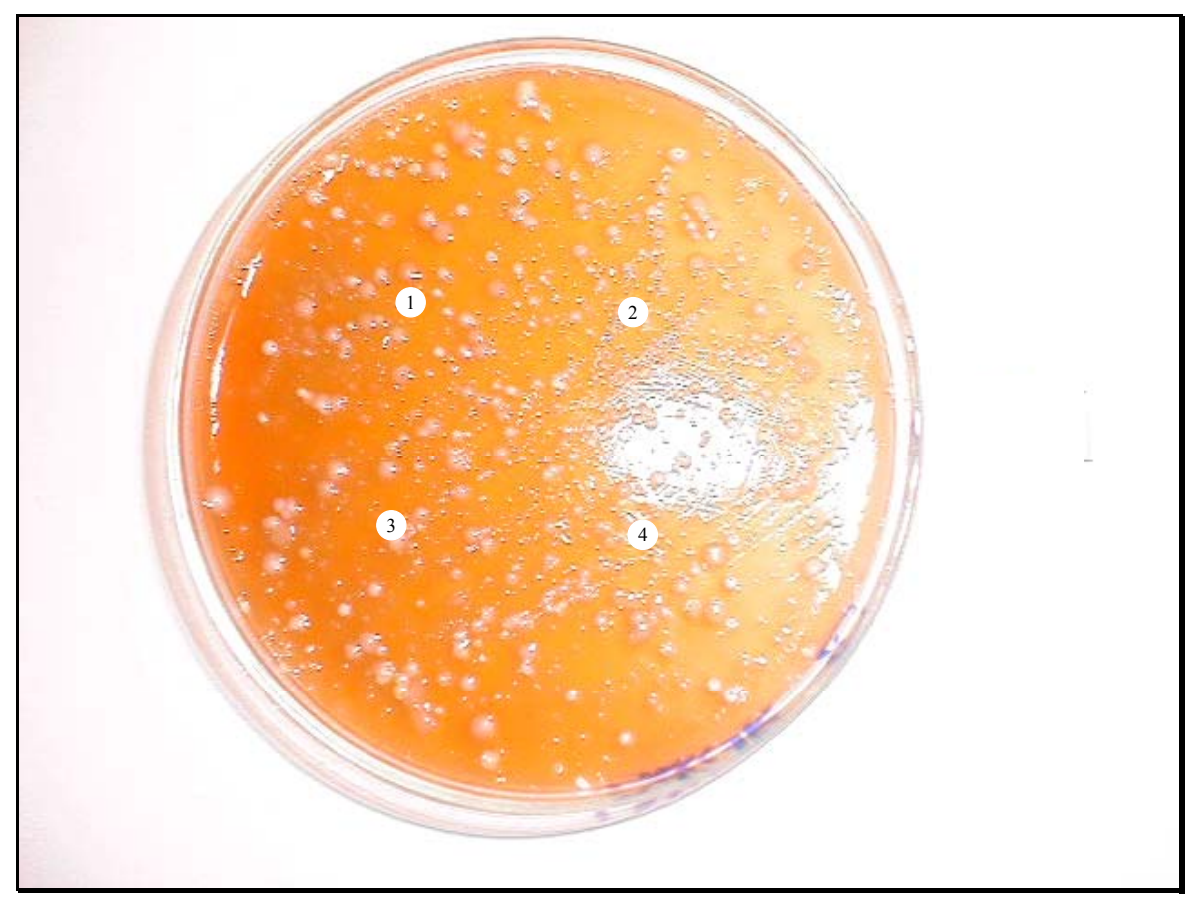

FIGURA 19 -Amostra de Streptococcus mutans em ágar sangue utilizada para o teste de sensibilidade. 1- $\mathrm{pH} 3,5 ; 2-\mathrm{pH} 4,0 ; 3$ - $\mathrm{pH} 4,5$ e 4 - $\mathrm{pH}$ 5,0, após 48 horas de incubação.

\section{IV.3.2. Testes de contato direto}

ZHENG \& ZHU (2003) avaliaram o efeito de diversas concentrações de quitosana, através do teste de contato direto este teste consiste em inocular as amostras sobre os meios de cultura e seguidamente espalhar uniformemente as soluções testadas; após os períodos de incubação, calcular o efeito inibitório das soluções. Esta mesma metodologia foi utilizada no presente estudo como preliminar para o teste de atividade.

Como não há dados disponíveis na literatura sobre a influência do $\mathrm{pH}$ na atividade antimicrobiana da quitosana, experimentos preliminares foram feitos em valores de $\mathrm{pH}$ entre 3,5 e 5,0. Fibras floculentas foram observadas 
para soluçòes de $\mathrm{pH}$ maior que 5,5 indicando a reprecipitação da quitosana dissolvida.

Os resultados obtidos (tabela 9) demonstraram que para as amostras de saliva (cultivadas em MSB e ágar sangue) o pH onde se observou um melhor efeito antimicrobiano foi o $\mathrm{pH} 5,0$.

Tabela 9. Influência do pH no efeito inibitório.

\begin{tabular}{lcc}
\hline & \multicolumn{2}{l}{ Efeito Inibitório \% } \\
\cline { 2 - 3 } $\begin{array}{c}\text { pH da } \\
\text { Quitosana }\end{array}$ & Amostras \\
\cline { 2 - 3 } & S. mutans & Saliva total \\
\hline 3,5 & 75 & 60 \\
4,0 & 80 & 68 \\
4,5 & 87 & 73 \\
5,0 & 95 & 81 \\
\hline
\end{tabular}

Levando-se em conta este resultado prosseguiu-se utilizando apenas as soluções de quitosana $\mathrm{pH}$ 5,0 para o estudo da influência da concentração e as associações com clorexidina. A influência da concentração de quitosana $\mathrm{pH} 5,0$ na atividade antimicrobiana foi estudada variando-se a concentração entre 0,1 e 1,5\%. Observou-se que o aumento da concentração de quitosana (tabela 10) demonstrou ser mais eficaz em relação ao efeito antimicrobiano. 
O aumento da concentração de quitosana nas soluções não é proporcional ao efeito inibitório, pois aumentando-se em mais de 10 vezes a concentração de quitosana este aumento do efeito inibitório não foi observado.

A diversidade de microrganismos presentes na saliva é a mais provável explicação para a discrepância entre os resultados, pois na saliva total podem existir microorganismos não patógenos, mais resistentes segundo JEON, et al 2001.

A diferença entre $\mathrm{o} \mathrm{pH}$ das soluções e dos meios dificultou $\mathrm{O}$ espalhamento das soluções sobre as amostras inoculadas, pois diminuiu a capacidade de molhar a superfície, sendo que talvez este fator possa ter interferido no efeito inibitório.

Tabela 10.Influência da concentração no efeito inibitório.

\begin{tabular}{lcc}
\hline \multirow{2}{*}{\begin{tabular}{c} 
Concentração $\begin{array}{l}\text { Ee } \\
\text { de } \\
\text { Quitosana }\end{array}$ \\
\cline { 2 - 3 }
\end{tabular}} & Amosto Inibitório \% \\
\cline { 2 - 3 } & S. mutans & Saliva total \\
\hline 0.1 & 72 & 51 \\
0,5 & 83 & 67 \\
1,0 & 95 & 81 \\
1,5 & 100 & 92 \\
\hline
\end{tabular}

Na Figura 20 é mostrado um conjunto de placas onde se pode observar o efeito inibitório das várias concentrações de quitosana sobre a amostra de saliva. Nota-se a diminuição do número de UFC. 


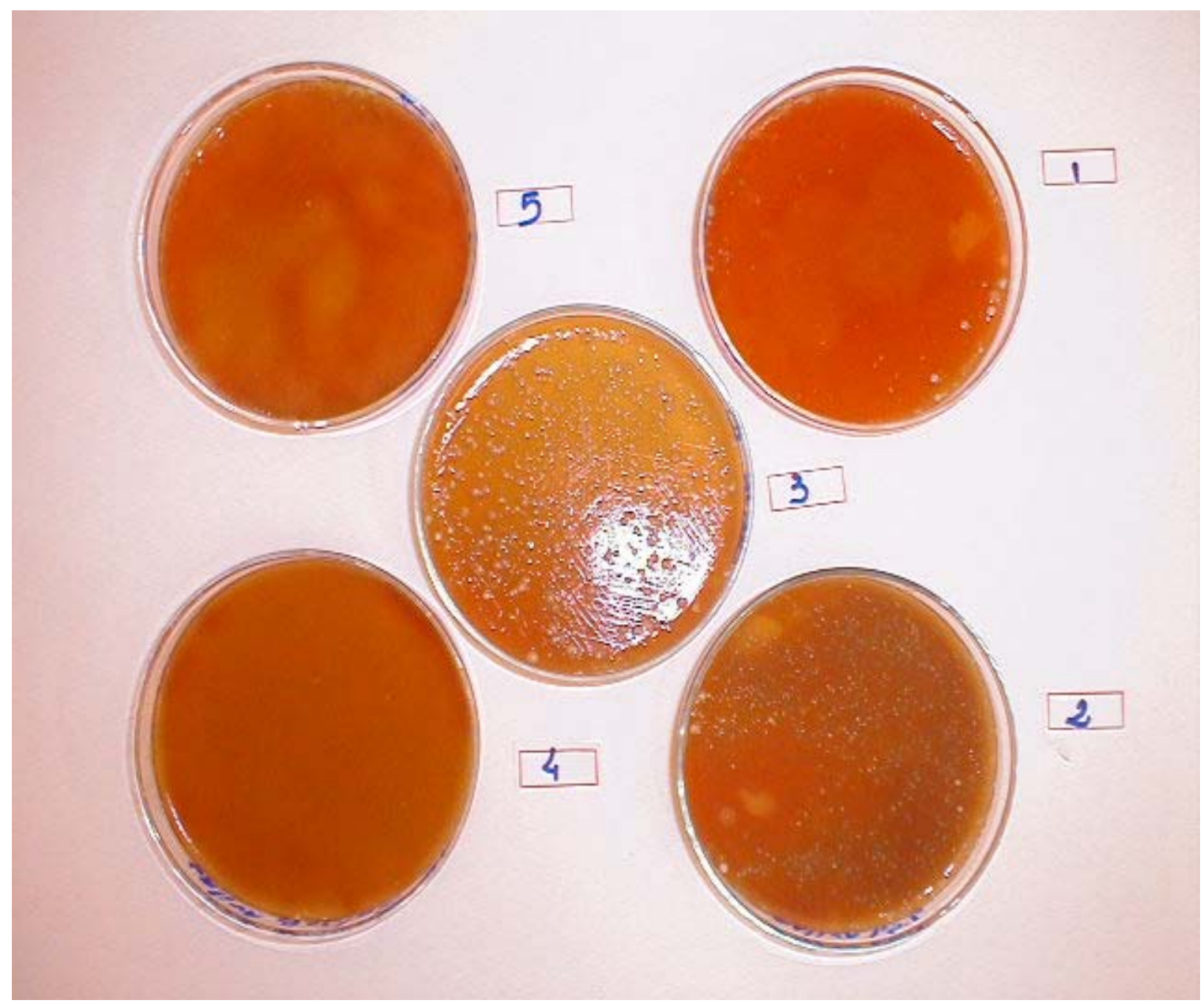

FIGURA 20. Efeito da concentração da quitosana sobre a saliva cultivada em ágar sangue, após 72 horas de incubação.(1)Quitosana 0,5\%; (2) Quitosana $0,1 \%$; (3) Controle, sem adição de quitosana ;(4) Quitosana 1,5\%; (5) Quitosana 1,0\%.

A obtenção dos resultados com as associações entre as substâncias são indicativas de que ocorre a potencialização entre as mesmas como mostrado na tabela 11, fato que evidencia que a utilização das mesmas é viável para a atividade antimicrobiana bem como para liberação continuada do 
princípio (clorexidina) como verificado por GIUNCHEDI, et al. (2002), que formularam tabletes bucais com as duas substâncias.

Tabela 11. Influência das soluções no efeito inibitório

\begin{tabular}{lcc}
\hline \multirow{2}{*}{ Soluções } & \multicolumn{2}{l}{ Efeito Inibitório \% } \\
\cline { 2 - 3 } & Amostras \\
\cline { 2 - 3 } & S. mutans & Saliva total \\
\hline Quitosana 0,1+Clor.0,06 & 95 & 61 \\
\hline Quitosana 0,1+Clor. 0,12 & 98 & 92 \\
\hline Quitosana 0,5+Clor, 0,06 & 98 & 76 \\
\hline Quitosana 0,5+Clor. 0,12 & 99 & 94 \\
\hline Quitosana 1,0+Clor. 0,06 & 100 & 96 \\
\hline Quitosana 1,0+Clor. 0,12 & 100 & 97 \\
\hline Quitosana 1,5+Clor. 0,06 & 100 & 100 \\
\hline Quitosana 1,5+Clor.0,12 & 100 & 100 \\
\hline Clorexidina 0,12 & 87 & 92 \\
\hline
\end{tabular}

\section{IV.4. ANÁLISE DA DENSIDADE ÓPTICA}

Pasteur foi quem inicialmente aplicou a visualização direta do aumento de turbidez em um meio liquido como critério para determinar o crescimento de um microrganismo (SILVA, 1999). Alguns instrumentos que medem a turbidez determinam a densidade óptica (DO), comparando-se a quantidade de luz que atravessa a suspensão microbiana com a quantidade de luz que atravessa uma suspensão-controle, sem partículas. 
A escolha deste teste foi devido ao fato de ser praticamente automatizado, enfatizando assim os resultados obtidos nos testes anteriormente realizados e tendo por finalidade observar se as diferentes concentrações de quitosana interferiam no crescimento bacteriano.

Em condições experimentais (sistema fechado), dependendo do ponto no qual o processo de crescimento seja interrompido pelo experimentador, o crescimento bacteriano passa por quatro fases características, que são: Fase lag - fase de adaptação metabólica ao novo ambiente, o número de indivíduos não aumenta nesta fase.

Fase exponencial ou logarítmica - fase na qual o número de células da população dobra a cada geração, esta taxa de crescimento não pode ser mantida em um sistema fechado, pois as condições ambientais tornam-se desfavoráveis pela a escassez de nutrientes, acumulo de metabólitos tóxicos e limitação de espaço.

Fase estacionária - fase em que a taxa de crescimento diminui significativamente devido às condições limitantes do meio e a taxa de divisão celular é muito próxima da taxa de morte celular, o que mantém constante o número de células viáveis na população.

Fase de declínio - fase de declínio exponencial do número de células viáveis. A taxa de morte torna-se maior que a taxa de divisão, o número de células viáveis entra em declínio progressivo até a completa extinção da população. 
A densidade óptica das amostras foi estabelecida em aproximadamente 0,8 por este valor estar dentro da fase exponencial de crescimento bacteriano.

Os resultados estão apresentados na figura 21, analisando-se 0 gráfico observa-se que a D.O. do controle negativo não foi igual a zero, sendo o esperado devido à viscosidade das soluções com concentrações maiores de quitosana, mas mesmo assim foi realizada a inoculação em ágar sangue, onde se verificou a ausência de crescimento bacteriano, confirmando então que a D.O. foi devido às características das soluções testadas, os valores da D.O. das soluções de quitosana sem bactérias foram descontados das amostras testadas.

A análise dos testes de D.O. confirmou que com o aumento da concentração de quitosana nas soluções aumenta-se também o efeito sobre as bactérias, pois quanto menor a densidade óptica melhor a atividade da quitosana em inibir o crescimento bacteriano. 


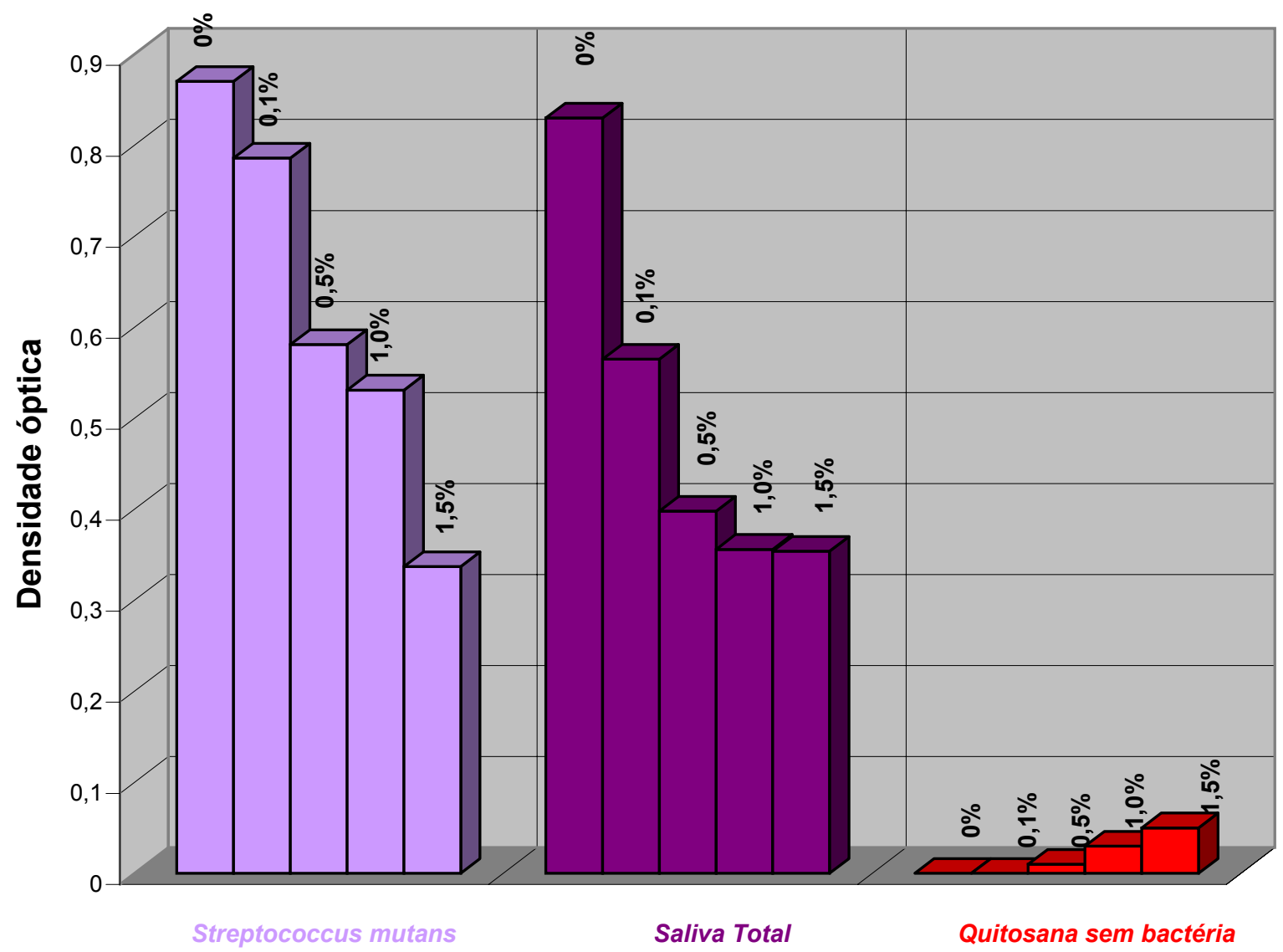

FIGURA 21: Densidade óptica das amostras expostas as soluções de quitosana e das soluções de quitosana. 
O teste de atividade, realizado pela exposição direta de cones contaminados às substâncias antimicrobianas, fornece informações qualitativas a respeito das substâncias através da verificação da presença de turvação dos meios (presença de crescimento bacteriano) ou não, expressando assim a efetividade das mesmas.

Como a quitosana a $1,5 \%$, associada ou não a clorexidina apresentou alto poder antimicrobiano para amostra de Streptococcus mutans, a mesma foi eleita para os testes de atividade. Estes estão relacionados à exposição direta dos microorganismos à efetividade da substância, parecendo ser independente de outras variáveis como, por exemplo: solubilidade e difusibilidade, como também um teste laboratorial prático, segundo ESTRELA, et al. (2000b).

Os tempos utilizados nos testes de atividade e nos testes de simulação de bochechos foram escolhidos por serem utilizados na prática clínica, através de aplicações tópicas intensivas ou mesmo o uso de soluções antissépticas. As tabelas 12 e 13 expressam os resultados obtidos sobre a saliva e S. mutans, respectivamente, demonstrando o efeito antimicrobiano das diferentes soluções testadas, nos períodos de 2, 3, 4 e 30 minutos.

Tabela 12: Efeito das diferentes soluções sobre a saliva.

\begin{tabular}{lcccc} 
Soluções & \multicolumn{4}{c}{ Tempo $(\min )$} \\
\cline { 2 - 5 } & 2 & 3 & 4 & 30
\end{tabular}


1- Quitosana 1,5\%

2-Quitosana 1,5\%+clor. 0,06\%

$++$

$---$

- - -

$--$

3-Quitosana 1,5\%+clor. 0,12\%

$+++$

$++$

4-Clorexidina $0,12 \%$

$+++++++$

5- Solução salina estéril

$++$

$++$

$++$

$++$

(-)negativo=ausência de crescimento;(+) positivo=presença de crescimento.

Tabela 13: Efeito das diferentes soluções sobre Streptococcus mutans. Soluções Tempo (min)

$\begin{array}{llll}2 & 3 & 4 & 30\end{array}$

1- Quitosana 1,5\%

$+++$

$-\cdots$

$-\cdot-$

$--$

2-Quitosana 1,5\%+clor. 0,06\%

3-Quitosana 1,5\%+clor. 0,12\%

$++$

$++$

4-Clorexidina $0,12 \%$

$+++$

$++$

5- Solução salina estéril

(-)negativo=ausência de crescimento;(+) positivo=presença de crescimento.

A efetividade da quitosana $1,5 \%$ foi observada no período de 3 minutos de exposição direta para amostras de saliva e de Streptococcus mutans, sendo os mesmos resultados para as duas associações, ou seja, para esta concentração de quitosana, nas condições deste teste, a clorexidina aparentemente não interferiu na efetividade, não importando a concentração da mesma.

A clorexidina $0,12 \%$ demonstrou ser efetiva para as duas amostras no período de 30 minutos. Para a solução controle, solução salina estéril, verificou-se o crescimento de microrganismos em qualquer dos períodos, ou seja, as células microbianas permaneceram viáveis. 
O controle negativo, representado por tubos de ensaio contendo os meios de cultura esterilizados, sem adição das amostras e das soluções testadas, evidenciou macroscopicamente a ausência de turvação. Assegurou-se assim a esterilização dos meios de cultura empregados neste teste. No controle positivo em que as amostras testadas foram colocadas diretamente no meio, verificando-se o crescimento bacteriano, ou seja, presença de turvação o que atestou a viabilidade das amostras.

\section{IV.6. TESTES DE SIMULAÇÃO DE BOCHECHO}

A importância do fator tempo na eficácia antimicrobiana das soluções usadas foi demonstrada nos testes de atividade. Tal fato indicou a necessidade de novos testes que associassem o fator tempo, por isso a simulação de bochechos foi realizada com o método de exposição direta das amostras às soluções testadas.

Os resultados obtidos com a exposição direta das amostras às soluções testadas nos intervalos de tempo de 1, 2, 3, 4 e 5 minutos estão nas tabelas 14 e 15.

Tabela 14: Efeito das soluções sobre Streptococcus mutans

\section{Efeito inibitório (\%)}

Soluções

\begin{tabular}{ccccc}
\hline \multicolumn{6}{c}{ Tempo $(\min )$} \\
\hline 1 & 2 & 3 & 4 & 5
\end{tabular}




\begin{tabular}{llllll}
\hline Solução salina estéril & $0 \%$ & $0 \%$ & $0 \%$ & $0 \%$ & $0 \%$ \\
Quitosana 0,1\% & $0 \%$ & $12 \%$ & $25 \%$ & $32 \%$ & $51 \%$ \\
Quitosana 0,5\% & $59 \%$ & $60 \%$ & $67 \%$ & $74 \%$ & $85 \%$ \\
Quitosana 1\% & $68 \%$ & $75 \%$ & $85 \%$ & $96 \%$ & $100 \%$ \\
Quitosana 1,5\% & $89 \%$ & $98 \%$ & $100 \%$ & $100 \%$ & $100 \%$ \\
Clorexidina & $59 \%$ & $68 \%$ & $76 \%$ & $88 \%$ & $100 \%$ \\
\hline
\end{tabular}

Tabela 15: Efeito das soluções sobre a saliva

$$
\text { Efeito inibitório (\%) }
$$

\begin{tabular}{lccccc}
\cline { 2 - 5 } \multicolumn{1}{c}{ Soluções } & \multicolumn{5}{c}{ Tempo (min) } \\
\cline { 2 - 6 } & 1 & 2 & 3 & 4 & 5 \\
\hline Solução salina estéril & $0 \%$ & $0 \%$ & $0 \%$ & $0 \%$ & $0 \%$ \\
Quitosana 0,1\% & $0 \%$ & $4 \%$ & $11 \%$ & $24 \%$ & $27 \%$ \\
Quitosana 0,5\% & $36 \%$ & $41 \%$ & $50 \%$ & $54 \%$ & $68 \%$ \\
Quitosana 1\% & $72 \%$ & $77 \%$ & $84 \%$ & $92 \%$ & $98 \%$ \\
Quitosana 1,5\% & $87 \%$ & $97 \%$ & $100 \%$ & $100 \%$ & $100 \%$ \\
Clorexidina & $4 \%$ & $11 \%$ & $17 \%$ & $89 \%$ & $100 \%$ \\
\hline
\end{tabular}

A efetividade das soluções aumentou com o tempo de exposição, ou seja, com o aumento do tempo a eficácia também aumentou, exceto para o controle (solução salina estéril) que mostrou a viabilidade das amostras em todos os tempos estudados. Para as duas amostras estudadas nos tempos de 3 , 4 e 5 minutos a quitosana a $1,5 \%$ apresentou alto poder antimicrobiano. A figura 22 mostra o efeito da quitosana a 1,5\% sobre amostra de S. mutans nos tempos de 2, 3, 4 e 5 minutos, este mesmo poder foi observado somente para amostra 
de Streptococcus mutans, exposta a quitosana a $1,0 \%$ e a clorexidina $0,12 \%$ no tempo de 5 minutos.

Observa-se na figura 22 (placa de número 1) onde o tempo de exposição da amostra à solução de quitosana a $1,5 \%$ foi de 2 minutos a pequena quantidade de UFC e que a partir de 3 minutos de exposição não houve crescimento bacteriano, evidenciando que a quitosana a 1,5\% apresenta melhores resultados que a clorexidina.

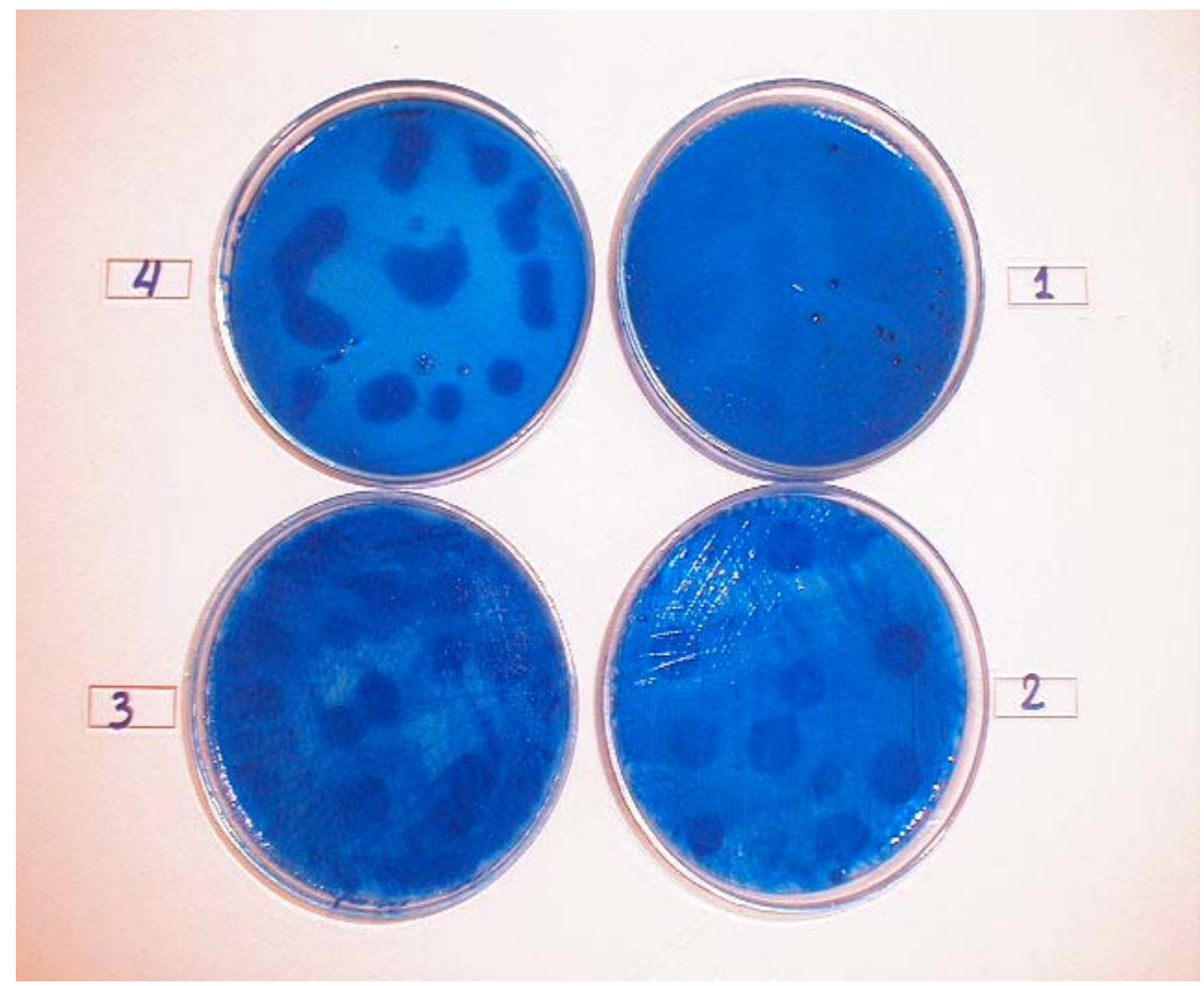

FIGURA 22- Efeito inibitório da quitosana a 1,5\% sobre Streptococcus mutans em função do tempo de exposição (1) 2 minutos, (2) 3 minutos, (3) 4 minutos, (4) 5 minutos, meio MSB, após 48 horas de incubação. 
Os resultados obtidos para concentração de quitosana de $0,1 \%$ demonstraram que o efeito inibitório foi menos eficaz contra as amostras, o que está de acordo com o estudo de CHOI, et al. (2001), que apesar da metodologia empregada e do tipo de quitosana serem diferentes, observaram que a redução dos Streptococcus mutans é pequena.

Observando-se os resultados nota-se que Streptococcus mutans são mais sensíveis às soluções testadas que os microorganismos totais da saliva, fato que pode estar relacionado com a maior efetividade contra microorganismos patógenos do que não patógenos como verificado por JEON, et al. (2001). 


\section{CONCLUSÕES}

1. Os resultados indicam que as amostras de saliva e de $S$. mutans foram sensíveis a quitosana e a clorexidina.

2. Os fatores $\mathrm{pH}$, concentração e tempo testados para quitosana influenciam no poder antimicrobiano, quanto maiores os fatores testados, maior o efeito antimicrobiano.

3. O fator tempo testado para a clorexidina influenciou nas amostras testadas, quanto maior o tempo de exposição melhor o efeito antimicrobiano.

4. A quitosana na concentração de $1,5 \%$ apresentou alto poder antimicrobiano, não permitindo o crescimento de nenhuma UFC contra os S. mutans.

5. A potencialização do efeito antimicrobiano mostrado, decorrente da combinação entre clorexidina e quitosana, evidencia a possibilidade de aplicações de clorexidina em concentrações menores, evitando assim os efeitos indesejáveis. 


\section{REFERÊNCIAS BIBLIOGRÁFICAS}

AXELSSON, P. Current role of pharmaceuticals in prevention of caries and periodontal disease. Int Dent J., Guiedford, v.433, p.473-482, 1983.

BARKVOLL, P., ROLLA, G., BELLAGAMBA, S. Interaction between chlorhexidine digluconate and sodium monofluorophospate in vitro. Scan J Dent Res., Copenhagen, v. 996, n.1, p. 303, 1988

BARKVOLL, P., ROLLA, G., SVENDSEN, A. K. Interaction between chlorhexidine gluconate annd sodium lauryl sulfate in vivo. $J$ Cin Periodontol, Copenhagen, v. 16, p. 593-595, 1989.

BELLINI, A. T., MORAES, F., FERRA, D. P. Uso da clorexidina no controle da placa e gengivite: Estudo comparativo da aplicação tópica na forma de bochechos. Rev APCD, São Paulo, v.34, n.4, p.267-282, Jul/ Ago 1980.

BONESVOLL, P. Influence of ionic strenght, calcium, sodium dodecyl sulfate and urea on the retention chlorhexidine in the human mouth after mouth rinses. Arch Oral Biol, Oxford, v.22, p. 273-279, 1977.

BOWDEN, G. H. Mutans atreptococci caries and chlorhexidine. J Can Dent Assoc, Otawa, v. 62, n. 9, p.700, Sep 1996.

CHANG, D. S., CHO, H. R., GOO, H. Y., CHOE, W.K. A. Development of Food Preservation with the Waste of Crab Processing in Bull. Korean Fish Soc, v.22, p. 70-78, 1989.

CHO, H. R., CHANG, D. S., LEE, W. D., JEONG, E. T., LEE, E. W. Utilization of chitosan hydrolisate as a natural food preservative for fish meat past products. Korean, J Food Sci Technol, v.30, n.4, p. 817-822, 1998.

CHOI, B-K, KIM, K-Y, YOO, Y-J, OH, S-J, CHOI, J-H, KIM, C-Y. In vitro antimicrobial activity of a chitooligosaccharide mixture against Actinobacillus actinomycetemcomitans and Streptococcuss mutans. Int J of Antimic Agents.v. 18, p. 553-557, 2001.

CLARK, D. C., GUEST, J. L. The effectiveness of three different strengths of chlorhexidine mouthrinse. J Can Dent assoc, Otawa, v. 60, n.8, p. 711-714, Aug 1994.

DARMADJI, P. \& IZUMIMOTO, M. Effect of chitosan in meat preservation. Meat Science,v.38, p. 243-254, 1994. 
DASANAYAKE, A.P., et al. Differences in the detection and enumeration of mutans streptococci due to differences in methods. Archs Oral Biol, Oxford, v. 40, n. 4, p. 345-351, 1995.

EMILSSON, C. G. Susceptibility of various microorganisms to chlorhexidine. Scand J Dent Res, Copenhagen, v. 85, p. 255-265,1977.

ESTRELA, C., ESTRELA, C. R. A., MOURA, J., BAMMANN, L.L. Testing calcium hydroxide antimicrobial potential by different methods. J dent Res, v. 79, p. 529 (IADR Abstract 3081), 2000b.

FRANDSEN, A. Mechanical oral hygiene practices. In: Dental plaque control measures and oral hygiene practices, Oxford: H. LOE \& D.V. KLEINMAN, IRL Press, p. 93-116, 1986.

GISSELSON, H., BIRKHED, D., BJORN, AA. L. Effect of professional flossing with chlorhexidine gel on aproximal caries in 12- to 15- year- old schoolchildren. Caries res, Basel, v. 22, p. 187-192, 1988.

GIUNCHEDI, P., JULIANO, C., GAVINI, E., COSSU, M., SORRENTI, M. Formulation and in vivo evaluation of chlorhexidine buccal tablets prepared using drug- loaded chitosan microspheres. Eur $\mathrm{J}$ Pharm annd Biopharrm, v.53, p. 233-239,2002.

GJERMO, P., et al. Relationship between plaque inhibiting effect and retention of chlorhexidine in the human oral cavity. Arch Oral Biol, v.19, n. 11, p. 1031-1034, Nov 1974.

GOLD, O. C., JORDAN, H.V., VAN HOUTE, J. A selective medium for $\mathbf{S}$ mutans. Arch Oral Biol, Oxford, v. 18, p. 1356-1364, 1973.

GREENSTEIN, G., BERMAN, C., JAFFIN, R. Chlorhexidine an adjunt to periodontal therapy. J periodontal. Chicago, v. 57, p. 370-377, 1986.

HELGELAND, K., HEYDEN, G., ROLLA, G. Effect of clhorhexidine on animals cells “ in vitro “. Scannnd J Dent Res, v. 79, n. 3, p. 209- 215, 1971.

HENNESSEY, T. D. Some antibacterial properties of chlorhexidine. J periodontal res, v. 12, p. 61-67, 1973.

HIRANO, S., SEINO, H., AKIYAMA, Y. NONAKA, I. Biocompatibility of chitosan by oral and intravenous administrations. Polym Mater Sci Eng, v. 59, p. 897-901, 1988. 
HOLBROOK, W. P. Dental caries and cariogenic factors in pre- school urban in icelandic children. Caries Res, v. 27, p. 431-437, 1993.

HUGO, W. B., LONGWORTH, A. R. The effect of chlorhexidine on the electrophoretic mobility, cytoplasmic constituents, dehydrogenase activity and cell walls of Escherichia coli and Staphylococcus aureus. J Pharm Pharmacol, London, v. 18, p. 569- 578, 1966.

IKINCI, G., SENEL, S., AKINCIBAY, H., KAS, S., ERCISS, S., WILSON, C. G., HINCAL, A. A. Effect of chitosan on a periodontal pathogen Porphyromonas gingivalis. Int J fo Pharm, v. 235, p. 121-127, 2002.

ISOKONGAS, P. et al. Dental caries and mutans streptococci in the proximal areas of molar affected by the habitual use of xylitol chewing gum. Caries Res, Basel, v. 25, p. 444- 448, 1991.

JEON, Y. J., PARK, P. J., KIM, S. K. Antimicrobial effect of chitooligosaccharides produced by bioreactor. Carbohydr Polym, v. 44, p. 71- 76, 2001.

JUNG, B. O., KIM, C. H., CHOI, K. S. YOUNG, M. L., KIM, J. J. Preparation of amphiphilic chitosan and their antimicrobial activities. J of Applied Pol Sci, v. 72, p. 1713-1719, 1999.

KIDD, E. A. M. Role of chlorhexidine in the management of dental caries. Int Dent Journal, v. 41, n. 5, p. 279- 286, Oct 1991.

KÖHLER, B., BRATTHALL, D., KRASSE, B. Preventive measures in mothers influence the establishment of the bacterium streptococcus mutans in their infants. Arch Oral Biol, n. 28, n. 3, p. 225-231, 1983

KUMAR, M. N. V. R. A review of chitin and chitosan applications. Reactive \& Functional Polymers, v. 46,p. 1-27, 2000.

LEE, K. Y., HA, W. S., PARK, W. H. Blood compatibilçity and biodegradability of partially $\mathrm{N}$ - acetylated chitosan. Biomat, v. 16, p. 12111216, 1995.

LINDHE, J. ET AL. Long term effect of surgical / non surgical treatment of periodontal disease. J Clin Periodontol, v. 11, p. 448-458, 1984.

MALTZ- TURKIENICZ, M., KRASSE, B., EMILSON, C. G. Effects of chlorhexidine and iodine on in vitro plaques of Streptococcus mutans and S. sanguis. Scand J dent Res, Copenhagen, v. 88, p. 28- 33, 1980. 
MUZZARELLI, R. A. AA. Chitin and human body. In DOMARD, A., JEUNIAUX, C., MUZZARELLI, R., ROBERTS, G. A. F., editors Advances in chitin science. Vol I. Lyon. J. André Publisher, 1996, p. 448-461.

MUZZARELLI, R., BALDASSARE, V., CONTI, F., FERRERA, P., BIAGINI, G., GAZZANELLI, G., VASI, V. Biological activity of chitosan ultrastructural atudy. Biomaterials, v. 9, p. 247-252, 1988.

NO, H. K., PARK, N. Y., LEE, S. H., HWANG, H. J., MEYERS, S. P. Antibacterial activities of chitosans and chitosan oligomers with different molecular weights on spoilage bacteria isolated from tofu. Food Microbiol and Safety, v.67, n.4, p. 1511-1514, 2002.

NO, H. K., PARK, N. Y., LEE, S. H., MEYERS, S. P. Antibacterial activity of chitosans and chitosan oligomers with different molecular weights. Int $\mathrm{J}$ of Food Microbiol, v. 74, p. 65-72, 2002.

NORDBO, $H$. Discoloration of human teeth by a combination of chlorhexidine and aldehydes or ketones in vitro. Scand J dent Res, v. 79, n. 5, p. 356- 361, 1971.

NORDTVEIT, R. J., VARUM, K. M., SMIDSROD, O. Degradation of fully water soluble partially $\mathbf{N}$ - acetylated chitosans with lysosyme. Carbohydr polym, $\mathrm{v}$. 23, p. 253-260, 1994.

OWENS, J., et al. A short- term clinical study design to investigate the chemical plaque inhibitory properties of mouthrinses when used as adjuncts to toothpastes: applied to chlorhexidine. J Clin Periodontol, v. 24, n. 10, p. 732-737, Oct. 1997.

PADETEC - Parque de Desenvolvimento Tecnológico - Universidade Federal do Ceará. Brasil. Disponível em < www. Padetec.ufc.br>. Acesso em 15 de março de 2004.

POLYMAR IND. COM. IMP. e EXP. LTDA - Fortaleza - Ceará. Disponível em $<$ www.polymar.com.br/quitosana/quito-apli.htm $>$. Acesso em 15 de março de 2004.

PONTON, J. Tema 34:Composición y ecología de la microbiota oral. Atualizado em 2000. Disponível em <www.ehu.es/roivmoral/microral.htmL. Acesso em 07 de julho de 2004.

PUCHER, J. J., DANIEL, J. C. The effects of chlorhexidine digluconate on human fibroblasts in vitro. J perodontol, v. 63, n. 6, p. 526-532, Jun 1992. 
RABEA, E. I. et al. Chitosan as Antimicrobial Agent:: Applications and Mode of Action. REVIEWS. Biomacromol, v. 4, n. 6, p.1457-1465, Nov/ Dec 2003.

RAMACCIATO, J. C. Atividade antimicrobiana de soluções à base de alho (Allium satirum ), óleo de melaleuca ( Melaleuca alternifólia ) e clorexidina sobre microoganismos totais e Estreptococos do grupo mutans. Estudo In Vivo. Dissertação apresentada à faculdade de Odontologia de Piracicaba da Universidade Estadual de Campinas, para obtenção do título de Mestre em Odontologia. Piracicaba, 2002, 88 p.

RAMBERG, P. et al. A model for studying the effects of muothrinses on the novo plaque formation. J Clin Periodontol, v. 19, n. 7, p. 509- 520, Aug 1992.

RATHKE, T. D.; HUDSON, S. M. Macromolecular Chemistry and Physics, v.C34, n.3, p.375-437, 1994.

ROBERTS, G. A. F. Chitin Chemlstry, Hampshire, Mac Millan, 1992.

ROLLA, G., LÖE, H., SCHIOTT, C. R. The affinity of chlorhexidine for hidroxiapatite and salivary mucins. J periodontal Res, v. 5, p. 79- 83, 1970.

ROLLA, G., MELSEN, B. On the mechanism of the plaque inhibition by chlorhexidine. J Dent Res, v. 54, p. 57- 62, 1975.

SANCHEZ COLLADO \& CIA. Disponível em: <http://www.sanchezcollado.com/ GLUCONATO.htm>.Acesso em 10 de abril de 2003.

SASHIMA, H., SAITO, K., SAIMOTA, H., MINAMI, S., OKAMOTO, Y., MATSUHASHI, A., SHIGEMASA, Y. Enzimatic degradation of chitin and chitosan. In Muzzarelli, R. A. A., editor. Chitin enzymology. Grottammare (AP), Ancona: Alda tecnografica, p. 177-186, 1993.

SEKIGUCHI, S., MIURA, Y., KANEKO, H., NISHIMURA, S. L., NISHI, N., IWASE, M., TOKURA, S. Molecular weight dependency of antimicrobial activity by chitosan oligomers. In: NISHINARI, K., DOI, E. ( Eds). Food Hydrocolloids: Structuress, Properties and Functions. Plenum, New York, p. 7176, 1994.

SHAHIDI, F., ARACHCHI, J. K. V., JEON, Y-J. Food applications of chitin and chitosans. Trends in Food Science \& Technology, v. 10, p. 37-51, 1999.

SHEPHERD, R., READER, S., FALSHAW, A. Chitosan functional properties. Glycoconjugate J, v.14, p. 535-542, 1997. 
SIGNINI, R. Estudos de obtenção, purificação e caracterização de quitosana. São Carlos, 1998. 110p. Dissertação (Mestrado) - Instituto de Química de São Carlos, Universidade de São Paulo.

SILVA, C. H. P. M. Bacteriologia: um texto ilustrado. $1^{\text {a }}$ edição, Teresópolis, RJ, editora, Eventos, 1999

SIMPSON, B. K., GAGNE, N., ASHIE, I. N. A., NOROOZI, E. Utilization of chitosan for preservation of raw shrimp ( Pandalus Boreali). Food biotechnol, v. 11, p. 25-44, 1997.

SUDARSHAN, N. R., HOOVER, D. G., KNORR, D. Antibacterial action of chitosan. Food biotech, v. 6, n. 3, p. 257- 272, 1992.

TARSI, R., MUZZARELLI, R. A. A., GUZMAN, C. A., PRUZZO, C. Inhibition of Streptococcus mutans adsorption to hydroxyapatite by low- molecularweight chitosans. J of Dental Research, v. 72, n. 2, p. 665-672, Feb 1997.

TOGELIUS, J. et al. Streptococcus mutans in saliva: intra- individual variations and relation to the number of colonized sites. Acta Odontol Scand, v. 42, p. 157- 163, 1984.

TONHI, E $\mu$. Obtenção e caracterização de blendas colágeno:quitosana para utilização como biomaterial, São Carlos, 1999. 89p. Dissertação (Mestrado) Instituto de Química de São Carlos, Universidade de São Paulo.

TRABULSI, L. R. \& ALTERTHUM, F. Microbiologia. 4 edição, São Paulo: Editora Atheneu, 2004.

UCHIDA, Y., IZUME, M., OHTAKARA, A. Preparation of chitosan oligomers with purifiied chitosanase and its application. In: SKJAK- BRAEK, G., ANTHONSEN, T., SANDFORD, P. ( Eds). Chitin and Chitosan: Sources, Chemistry, Biochemistry, Physical properties andd applications. $1^{\mathrm{a}}$ ed, Elsevier, London, p. 373- 382, 1989.

VAAHTONIEMI, L. H. Surface ultrastruturee of intact in situ chlorhexidinetreated human bucal cells. Acta Odontol Scand, v. 55, p. 277- 281, 1997.

XIE, W., XU, P., WANG, W., LIU, Q. Preparation and antibacterial activity of a water- soluble chitosan derivative. Carbohy Polymers, v. 50, p. 35-40, 2002.

ZICKERT, I., EMILSON, C. G., EKBLOM, K. et al. Prolonged oral reduction on Streptococcus mutans in humans after chlorhexidine disinfection followed by fluoride treatment. Scan J Dent Res, v. 95, p. 315- 319, 1987. 
ZICKERT, I., EMILSON, C. G., KRASSE, B. Correlationn of level and duration of Streptococcus mutans infection with incidence of dental caries. Infect Immun, Washington, v. 39, p. 982- 985, 1983.

ZHENG, L-Y., ZHU, J-F. Study on antimicrobial activity of chitosan with different molecular weights. Carbohy Polymers, v. 54, p. 527- 530, 2003.

WANG, G. Inhibition and Inactivation of five species of foodborne pathogens by chitosan. J Food Protection, v. 55, p. 916- 919, 1992. 


\section{ANEXO 1}

Preparo da Escala Padrão de Macfarland (SILVA, 1999).

1- Colocar 10 tubos em uma estante (todos do mesmo tamanho) e marcá-los de 1 a 10

2- Adicionar a seguinte quantidade de solução de cloreto de bário $\left(\mathrm{BaCl}_{2}\right)$ a $1 \%$ :

$\begin{array}{ll}\text { Tubo } \mathrm{n}^{\circ} 1 & 0,1 \mathrm{~mL} \\ \text { Tubo } \mathrm{n}^{\circ} 2 & 0,2 \mathrm{~mL} \\ \text { Tubo } \mathrm{n}^{\circ} 3 & 0,3 \mathrm{~mL} \\ \text { Tubo } \mathrm{n}^{\circ} 4 & 0,4 \mathrm{~mL} \\ \text { Tubo } \mathrm{n}^{\circ} 5 & 0,5 \mathrm{~mL} \\ \text { Tubo } \mathrm{n}^{\circ} 6 & 0,6 \mathrm{~mL} \\ \text { Tubo } \mathrm{n}^{\circ} 7 & 0,7 \mathrm{~mL} \\ \text { Tubo } \mathrm{n}^{\circ} 8 & 0,8 \mathrm{~mL} \\ \text { Tubo } \mathrm{n}^{\circ} 9 & 0,9 \mathrm{~mL} \\ \text { Tubo } \mathrm{n}^{\circ} 10 & 1,0 \mathrm{~mL}\end{array}$

3- Adicionar a cada tubo, quantidade suficiente de solução de ácido sulfúrico $\left(\mathrm{H}_{2} \mathrm{SO}_{4}\right)$ a $1 \%$ até completar $10 \mathrm{~mL}$ de solução;

4- Fechar bem os tubos (selar com parafina se eles não possuírem tampa de rosca);

5- Quando o precipitado de cor branca (de sulfato de bário) se formar em cada tubo, as densidades deles serão diferentes; a densidade de cada tubo corresponde, aproximadamente, ao seguinte número de bactérias por cada $\mathrm{mL}$ de solução:

$\begin{array}{lr}\text { Tubo } \mathrm{n}^{\circ} 1 & 300000 \\ \text { Tubo } \mathrm{n}^{\circ} 2 & 600000 \\ \text { Tubo } \mathrm{n}^{\circ} 3 & 900000 \\ \text { Tubo } \mathrm{n}^{\circ} 4 & 1200000 \\ \text { Tubo } \mathrm{n}^{\circ} 5 & 1500000 \\ \text { Tubo } \mathrm{n}^{\circ} 6 & 1800000\end{array}$


Tubo $\mathrm{n}^{\circ} 7 \quad 2100000$

Tubo $\mathrm{n}^{\circ} 8 \quad 2400000$

Tubo $n^{\circ} 9 \quad 2700000$

Tubo $\mathrm{n}^{\circ} 10 \quad 3000000$ 


\section{ANEXO 2}

Coloração de Gram (SILVA, 1999)

Em uma lâmina, fazer um esfregaço homogêneo, delgado, deixá-lo secar e fixálo na chama do bico de Bunsen.

1- corar por cerca de 1 minuto com solução de cristal violeta;

2- lavar com água corrente;

3- cobrir o esfregaço com solução de lugol por cerca de 1 minuto;

4- lavar com água corrente;

5- descorar com etanol (ou solução etanol + acetona $50 \% \mathrm{v} / \mathrm{v}$ ) até que não escorra cristal violeta do esfregaço;

6- lavar com água corrente;

7- corar com fucsina fenicada de Ziehl por cerca de 1 minuto;

8- lavar com água corrente;

9- deixar secar. Após, observar em objetiva de imersão em óleo. 